\title{
The
}

University

of Chicago

Law Review

VOLUME 55 NUMBER 1 WINTER 1988

- 1988 by The University of Chicago

\section{Jurisprudence and Gender}

\author{
Robin West† \\ INTRODUCTION
}

What is a human being? Legal theorists must, perforce, answer this question: jurisprudence, after all, is about human beings. The task has not proven to be divisive. In fact, virtually all modern American legal theorists, like most modern moral and political philosophers, either explicitly or implicitly embrace what I will call the "separation thesis" about what it means to be a human being: a "human being," whatever else he is, is physically separate from all other human beings. I am one human being and you are another, and that distinction between you and me is central to the meaning of the phrase "human being." Individuals are, in the words of one commentator, "distinct and not essentially connected with one another." We are each physically "boundaried"- -this is the trivially true meaning of the claim that we are all individuals. In Robert Nozick's telling phrase, the "root idea" of any accept-

$\dagger$ Professor of Law, The University of Maryland. I would like to thank Mike Kelly, Paul Brest, Lynne Henderson, Robert B. Green, Jana Singer, Peter Quint, Cass Sunstein, Richard Posner, Erin Enright, Quincie Hopkins, Tom Grey, the participants in the Wisconsin 1987 Feminism and Legal Theory Summer Workshop, and the Georgetown Feminist Legal Theory Workshop for their comments on early drafts of this article. I am also indebted to Marcy Wilder (Stanford Law School '88) for helping me to clarify and develop the critique of the critical legal scholarship discussed in this article.

1 Naomi Scheman, Individualism and the Objects of Psychology, in Sandra Harding and Merrill B. Hintikka, eds., Discovering Reality 225, 237 (1983). 
able moral or political philosophy is that "there are individuals with separate lives."2 Although Nozick goes on to derive from this insight an argument for the minimal state, the separation thesis is hardly confined to the libertarian right. According to Roberto Unger, premiere spokesperson for the communitarian left, "[t]o be conscious is to have the experience of being cut off from that about which one reflects: it is to be a subject that stands over against its objects ... . The subjective awareness of separation . . defines consciousness."3 The political philosopher Michael Sandel has recently argued that most (not all) modern political theory is committed to the proposition that "[w]hat separates us is in some important sense prior to what connects us-epistemologically prior as well as morally prior. We are distinct individuals first, and then we form relationships and engage in co-operative arrangements with others; hence the priority of plurality over unity." The same commitment underlies virtually all of our legal theory. Indeed, Sandel's formulation may be taken as a definitive restatement of the "separation thesis" that underlies modern jurisprudence.

The first purpose of this essay is to put forward the global and critical claim that by virtue of their shared embrace of the separation thesis, all of our modern legal theory-by which I mean "liberal legalism" and "critical legal theory" collectively-is essentially and irretrievably masculine. My use of " $\mathrm{I}$ " above was inauthentic, just as the modern, increasing use of the female pronoun in liberal and critical legal theory, although well-intended, is empirically and experientially false. For the cluster of claims that jointly constitute the "separation thesis"- the claim that human beings are, definitionally, distinct from one another, the claim that the referent of " $\mathrm{I}$ " is singular and unambiguous, the claim that the word "individual" has an uncontested biological meaning, namely that we are each physically individuated from every other, the claim that we are individuals "first," and the claim that what separates us is epistemologically and morally prior to what connects us-while "trivially true" of men, are patently untrue of women. Women are not essentially, necessarily, inevitably, invariably, always, and forever separate from other human beings: women, distinctively, are quite clearly "connected" to another human life when pregnant. In fact, women are in some sense "connected" to life and to other

2 Robert Nozick, Anarchy, State, and Utopia 33 (1974).

${ }^{3}$ Roberto Mangabeira Unger, Knowledge and Politics 200 (1975) (citation omitted)(emphasis added).

- Michael J. Sandel, Liberalism and the Limits of Justice 133 (1982). 
human beings during at least four recurrent and critical material experiences: the experience of pregnancy itself; the invasive and "connecting" experience of heterosexual penetration, which may lead to pregnancy; the monthly experience of menstruation, which represents the potential for pregnancy; and the post-pregnancy experience of breast-feeding. Indeed, perhaps the central insight of feminist theory of the last decade has been that woman are "essentially connected," not "essentially separate," from the rest of human life, both materially, through pregnancy, intercourse, and breast-feeding, and existentially, through the moral and practical life. If by "human beings" legal theorists mean women as well as men, then the "separation thesis" is clearly false. If, alternatively, by "human beings" they mean those for whom the separation thesis is true, then women are not human beings. It's not hard to guess which is meant.

Parts One and Two of this Article will contrast the "human being" constructed and described by (non-legal) feminist theory, with the "human being" constructed, described, or simply assumed by masculine jurisprudence. I will try to show that the "human being" sometimes explicated, and most often simply assumed by our modern legal theory contrasts in every particular with the "woman" sometimes assumed but more often carefully constructed by modern feminist theory. That contrast, however, is not a simple one. Neither masculine jurisprudence nor feminist theory is internally hegemonic. First, masculine jurisprudence is presently divided into two camps: "liberal legalism" on the one hand, and "critical legal theory" on the other. While both liberal legal theorists and critical legal theorists subscribe to the "separation thesis" described above, each group presents radically divergent accounts of what I will call the "subjective experience" of the state of separation. Similarly, "feminist theory" is sharply divided between "cultural feminism" on the one hand and "radical feminism" on the other. And, in a parallel sense, while both cultural and radical feminists subscribe to the "connection thesis" described above, they present divergent accounts of the subjective experience of the state of connection. Therefore, the first two parts of this article will present what is ultimately a four-way contrast between the complex and possibly conflicted human being constructed by masculine jurisprudence on the one hand, and the complex and possibly conflicted woman constructed by feminist theory on the other.

The third part of the Article discusses the possibility for, the promise of, the obstacles to, and the present status of a truly feminist jurisprudence, which I define as a jurisprudence built upon 
feminist insights into women's true nature, rather than upon masculine insights into "human" nature. The gap between the description of human nature assumed or explicated by legal theory and the description of women explicated by feminist theory reflects a very real political obstacle to the development of a "feminist jurisprudence:" feminists take women's humanity seriously, and jurisprudence does not, because the law does not. Until that fact changes, "feminist jurisprudence" is a political impossibility. The virtual abolition of patriarchy-a political structure that values men more than women-is the political precondition of a truly ungendered jurisprudence.But the gap between legal theory's descriptions of human nature and women's true nature also presents a conceptual obstacle to the development of feminist jurisprudence: jurisprudence must be about the relationship of human beings to law, and feminist jurisprudence must be about women. Women, though, are not human beings. Until that philosophical fact changes, the phrase "feminist jurisprudence" is a conceptual anomaly. Nevertheless, it does not follow that there is "no such thing" as feminist jurisprudence, any more than it follows from the dominant definition of a "human being" that there is no such thing as women. The second purpose of this paper is to explore and improve upon the feminist jurisprudence we have generated to date, in spite of patriarchy, and in spite of the masculinity of mainstream jurisprudence. Part two aims to schematize, review, and to some extent redirect that jurisprudence.

Finally, the conclusion suggests how a humanist jurisprudence might evolve, and how feminist legal theory can contribute to its creation.

\section{Masculine Jurisprudence and Feminist Theory}

The by now very well publicized split in masculine jurisprudence between legal liberalism and critical legal theory can be described in any number of ways. The now standard way to describe the split is in terms of politics: "liberal legal theorists" align themselves with a liberal political philosophy which entails, among other things, allegiance to the Rule of Law and to Rule of Law virtues, while "critical legal theorists," typically left wing and radical, are skeptical of the Rule of Law and the split between law and politics which the Rule of Law purportedly delineates. Critical legal theorists are potentially far more sensitive to the political underpinnings of purportedly neutral legalistic constructs than are liberal legalists. I think this traditional characterization is wrong for a number of reasons: liberal theorists are not necessarily politi- 
cally naive, and critical theorists are not necessarily radical. However, my purpose is not to critique it. Instead, I want to suggest another way to understand the divisions in modern legal theory.

An alternative description of the difference (surely not the only one) is that liberal legal theory and critical legal theory provide two radically divergent phenomenological descriptions of the paradigmatically male experience of the inevitability of separation of the self from the rest of the species, and indeed from the rest of the natural world. Both schools, as we shall see, accept the separation thesis; they both view human beings as materially (or physically) separate from each other, and both view this fact as fundamental to the origin of law. But their accounts of the subjective experience of physical separation from the other-an individual other, the natural world, and society-are in nearly diametrical opposition. Liberal legalists, in short, describe an inner life enlivened by freedom and autonomy from the separate other, and threatened by the danger of annihilation by him. Critical legal theorists, by contrast, tell a story of inner lives dominated by feelings of alienation and isolation from the separate other, and enlivened by the possibility of association and community with him. These differing accounts of the subjective experience of being separate from others, I believe, are at the root of at least some of the divisions between critical and liberal legal theorists. I want to review each of these experiential descriptions of separation in some detail, for I will ultimately argue that they are not as contradictory as they first appear. Each story, I will suggest, constitutes a legitimate and true part of the total subjective experience of masculinity.

I will start with the liberal description of separation, because it is the most familiar, and surely the most dominant. According to liberal legalism, the inevitability of the individual's material separation from the "other," entails, first and foremost, an existential state of highly desirable and much valued freedom: because the individual is separate from the other, he is free of the other. Because I am separate from you, $m y$ ends, $m y$ life, $m y$ path, $m y$ goals are necessarily my own. Because I am separate, I am "autonomous." Because I am separate, I am existentially free (whether or not I am politically free). And, of course, this is true not just of me, but of everyone: it is the universal human condition. We are each separate and we are all separate, so we are each free and we are all free. We are, that is, equally free.

This existential condition of freedom in turn entails the liberal's conception of value. Because we are all free and we are each equally free, we should be treated by our government as free, and 
as equally free. The individual must be treated by his government (and by others) in a way that respects his equality and his freedom. The government must honor at the level of politics the existential claim made above: that my ends are my ends; that I cannot be forced to embrace your ends as my own. Our separation entails our freedom which in turn entails our right to establish and pursue our own concept of value, independent of the concept of value pursued or favored by others. Ronald Dworkin puts the point in this way:

What does it mean for the government to treat its citizens as equals? That is . . . the same question as the question of what it means for the government to treat all its citizens as free, or as independent, or with equal dignity .... . [To accord with this demand, a government must] be neutral on what might be called the question of the good life. . . . [P]olitical decisions must be, so far as is possible, independent of any particular conception of the good life, or of what gives value to life. Since the citizens of a society differ in their conceptions, the government does not treat them as equals if it prefers one conception to another, either because the officials believe that one is intrinsically superior, or because one is held by the more numerous or more powerful group. ${ }^{5}$

Because of the dominance of liberalism in this culture, we might think of autonomy as the "official" liberal value entailed by the physical, material condition of inevitable separation from the other: separation from the other entails my freedom from him, and that in turn entails my political right to autonomy. I can form my own conception of the good life, and pursue it. Indeed, any conception of the good which $I$ form, will necessarily be $m y$ conception of the good life. That freedom must be respected. Because I am free, I value and have a right to autonomy. You must value it as well. The state must protect it. This in turn implies other (more contested) values, the most important of which is (or may be) equality. Dworkin continues:

I now define a liberal as someone who holds. . . . [a] liberal ... theory of what equality requires. Suppose that a liberal is asked to found a new state. $\mathrm{He}$ is required to dictate its constitution and fundamental institutions. He must propose a

B Ronald Dworkin, A Matter of Principle 191 (1985)(capitalization omitted)(emphasis added). 
general theory of political distribution .... He will arrive initially at something like this principal of rough equality: resources and opportunities should be distributed, so far as possible, equally, so that roughly the same share of whatever is available is devoted to satisfying the ambitions of each. Any other general aim of distribution will assume either that the fate of some people should be of greater concern than that of others, or that the ambitions or talents of some are more worthy, and should be supported more generously on that account. $^{6}$

Autonomy, freedom and equality collectively constitute what might be called the "up side" of the subjective experience of separation. Autonomy and freedom are both entailed by the separation thesis, and autonomy and freedom both feel very good. However, there's a "down side" to the subjective experience of separation as well. Physical separation from the other entails not just my freedom; it also entails my vulnerability. Every other discrete, separate individual--because he is the "other"-is a source of danger to me and a threat to my autonomy. I have reason to fear you solely by virtue of the fact that I am me and you are you. You are not me, so by definition $m y$ ends are not your ends. Our ends might conflict. You might try to frustrate my pursuit of my ends. In an extreme case, you might even try to kill me-you might cause my annihilation.

Annihilation by the other, we might say, is the official harm of liberal theory, just as autonomy is its official value. Hobbes, of course, gave the classic statement of the terrifying vulnerability that stems from our separateness from the other:

Nature hath made men so equall, in the faculties of body, and mind; as that though there bee found one man sometimes manifestly stronger in body, or of quicker mind then [sic] another; yet when all is reckoned together, the difference between man, and man, is not so considerable, as that one man can thereupon claim to himselfe any benefit, to which another may not pretend, as well as he. For as to the strength of body, the weakest has strength enough to kill the strongest, either by secret machination, or by confederacy with others, that are in the same danger with himselfe . . . . From this equality of ability, ariseth equality of hope in the attaining of our Ends. And therefore if any two men desire the same thing, which

- Id. at 192-3 (capitalization omitted). 
neverthelesse they cannot both enjoy, they become enemies; and in the way to their End, (which is principally their owne conservation, ....) endeavour to destroy, or subdue one an other. And from hence it comes to passe, that where an Invader hath no more to feare, than another mans single power; if one plant, sow, build, or possesse a convenient Seat, others may probably be expected to come prepared with forces united, to dispossesse, and deprive him, not only of the fruit of his labour, but also of his life, or liberty. And the Invader again is in the like danger of another. ${ }^{7}$

Bruce Ackerman gives a more modern rendition, but the message is essentially the same:

So long as we live, there can be no escape from the struggle for power. Each of us must control his body and the world around it. However modest these personal claims, they are forever at risk in a world of scarce resources. Someone, somewhere, will-if given the chance-take the food that sustains or the heart that beats within. Nor need such acts be attempted for frivolous reasons-perhaps my heart is the only thing that will save a great woman's life, my food sufficient to feed five starving men. No one can afford to remain passive while competitors stake their claims. Nothing will be left to reward such self-restraint. Only death can purchase immunity from hostile claims to the power I seek to exercise. ${ }^{8}$

Thus, according to liberal legalism, the subjective experience of physical separation from the other determines both what we value (autonomy) and what we fear (annihilation). We value, and seek societal protection, of our autonomy: the liberal insists on my right to define and pursue my own life, my own path, my own identity, and my own conception of the good life free of interference from others. Because I am me and you are you, I value what I value, and you value what you value. The only value we truly share, then, is our joint investment in autonomy from each other: we both value our right to pursue our lives relatively free of outside control. We can jointly insist that our government grant us this protection. We also share the same fears. I fear the possibility-indeed the likelihood-that our ends will conflict, and you will frustrate my ends and in an extreme case cause my annihila-

7 Thomas Hobbes, Leviathan 183-84 (C.B. Macpherson, ed. 1968).

${ }^{8}$ Bruce A. Ackerman, Social Justice in the Liberal State 3 (1980) (emphasis added). 
tion, and you fear the same thing about me. I want the right and the power to pursue my own chosen ends free of the fear that the you will try to prevent me from doing so. You, of course, want the same.

We can call this liberal legalist phenomenological narrative the "official story" of the subjectivity of separation. According to the official story, we value the freedom that our separateness entails, while we seek to minimize the threat that it poses. We do so, of course, through creating and then respecting the state. Whether or not Robert Nozick is right that the minimal state achieves the liberal's ideal, he has nevertheless stated that liberal ideal well in the following passage:

The minimal state treats us as inviolate individuals . . .; it treats us as persons having individual rights with the dignity this constitutes. . . . [This treatment] allows us, individually or with whom we choose, to choose our life and to realize our ends and our conception of ourselves, insofar as we can, aided by the voluntary cooperation of other individuals possessing the same dignity. How dare any state or group of individuals do more. Or less. . . . [T] [There is no social entity with a good that undergoes some sacrifice for its own good. There are only individual people, different individual people, with their own individual lives. Using one of these people for the benefit of the others, uses him and benefits others. Nothing more. ${ }^{8}$

Now, Critical Legal Theory diverges from liberal legalism on many points, but one striking contrast is this: critical theorists provide a starkly divergent phenomenological description of the subjective experience of separation. According to our critical legal theorists, the separate individual is indeed, in Sandel's phrase, "epistemologically prior to the collective." Like liberal legalists, critical legal theorists also view the individual as materially separate from the rest of human life. But according to the critical theorist, what that material state of separation existentially entails is not a perpetual celebration of autonomy, but rather, a perpetual longing for community, or attachment, or unification, or connection. The separate individual strives to connect with the "other" from whom he is separate. The separate individual lives in a state of perpetual dread not of annihilation by the other, but of the alienation, loneliness, and existential isolation that his material

- Nozick, Anarchy, State, and Utopia at 333-34, 32-33 (emphasis in original) (cited in note 2). 
separation from the other imposes upon him. The individual strives through love, work, and government to achieve a unification with the other, the natural world, and the society from which he was originally and continues to be existentially separated. The separate individual seeks community-not autonomy-and dreads isolation and alienation from the other-not annihilation by him. If we think of liberalism's depiction of the subjectivity of separation as the official story, then, we might think of this alternative description of the subjectivity of separation as the unofficial story. It is the subterranean, unofficial story of the unrecognized and-at least by liberals-slightly detested subjective craving of lost individuals.

Thus, there is a vast gap, according to critical theory, between the "official value" of liberal legalism-autonomy-and what the individual truly subjectively desires, which is to establish a true connection with the other. Similarly, there is a vast gap between the "official harm" of liberal legalism-annihilation by the other-and what the individual truly subjectively dreads, which is not annihilation by him, but isolation and alienation from him. According to the critical theorist, while the dominant liberal culture insists we value autonomy and fear the other, what the individual truly desires, craves, and longs to establish is some sort of connection with the other, and what the individual truly dreads is alienation from him. Robert Unger describes the terror that separation inflicts upon the individual in this way:

Consciousness, then, is the sign of the self's distance from the world. If one could imagine this separateness from nature in its pure form, before it was counterbalanced by the effects of human activity, its sign would be the experience of terror before the strangeness of the world. Because this terror is the mark of that very separation between self and nature upon which consciousness itself is based, it has never been driven completely out of conscious life. On the contrary, the strength of the social bond, the willingness to accept almost every form of degradation and enslavement at the hands of society, owes much to the need men have of belonging to a social world in which the foreignness of a pre-human nature does not prevail. ${ }^{10}$

Indeed, the individual longs to reestablish connection with the other in spite of the very real possibility (acknowledged by most if

10 Unger, Knowledge and Politics at 201 (emphasis added)(cited in note 3). 
not all critical theorists) that that other might, at any moment, frustrate his ends, threaten his autonomy, or annihilate him. But this longing for community survives in the face of an even more powerful source of resistance. The longing for attachment to the other persists in spite of the dominant liberal culture's adamant denial of the desire's existence. Peter Gabel describes the longing for connection in this way:

Let me start by making a descriptive assertion that may be controversial but which seems to me nonetheless self-evidently true-we are constituted as social beings by the desire to be recognized by others in an empowering, life-giving way. It is this fundamental experiential need that animates a baby's search for "eye-contact" with mother as well as the organizational efforts of adults who try to form into groups to vitalize their work-situations through the achievement of solidarity. While our actions are obviously also motivated by other factors . . . it is the desire to connect through this confirming or genuine reciprocity that gives to our actions their distinctive social energy, impelling us out toward the other even when . . . the likelihood of success seems very small.11

In another sense, though, the longing for connection persists not so much "in spite of" the dominant culture's valuation of autonomy, but because of that value. The value we place on autonomy, according to some critical legal theorists, aggravates our alienation, isolation and loneliness. Duncan Kennedy describes the feeling:

The "freedom" of individualism is negative, alienated and arbitrary. It consists in the absence of restraint on the individual's choice of ends, and has no moral content whatever. When the group creates an order consisting of spheres of autonomy separated by (property) and linked by (contract) rules, each member declares her indifference to her neighbor's salvation-washes her hands of him the better to "deal" with him. The altruist asserts that the staccato alternation of mechanical control and obliviousness is destructive of every value that makes freedom a thing to be desired. We can achieve real freedom only collectively, through group self-determination. We are simply too weak to realize ourselves in

12 Peter Gabel, The Phenomenology of Rights-Consciousness and the Pact of the Withdrawn Selves, 62 Tex.L.Rev. 1563, 1566-7 (1984)(citation omitted). 
isolation .... The problem is the conversion of force into moral force, in the fact of the experience of moral indeterminacy. A definition of freedom that ignores this problem is no more than a rationalization of indifference, or the velvet glove for the hand of domination through rules. ${ }^{12}$

The longing for connection with the other, and the dread of alienation from him, according to the critical theorists, is in a state of constant "contradiction" with the official value and official harm that flow from separation-autonomy from the other and annihilation by him. Nevertheless, in spite of that tension, both the dread of alienation and the desire for connection are constantly there. The dominant culture insists we value autonomy from the other and fear annihilation by him. But subjectively, the individual lives with a more or less unrealized desire to connect with the other, and a constant dread or fear, of becoming permanently alienated, isolated-lost-from the other.

To summarize: according to liberal legalism, each of us is physically separate from every other, and because of that separation, we value our autonomy from the other and fear our annihilation by him. I have called these our "officially" recognized values and harms. Critical legal theory tells the unofficial story. According to critical legal theory, we are indeed physically separate from the other, but what that existentially entails is that we dread the alienation and isolation from the separate other, and long for connection with him. While liberal culture officially and publicly claims that we love our autonomy and fear the other, subjective life belies this claim. Subjectively, and in spite of the dominant culture's insistence to the contrary, we long to establish some sort of human connection with the other in order to overcome the pain of isolation and alienation which our separateness engenders. These two contrasting stories of the subjective experience of perpetual separation from the rest of human life might be schematized in this way:

${ }^{22}$ Duncan Kennedy, Form and Substance in Private Law Adjudication, 89 Harv.L.Rev. 1685, 1774 (1976). 
(The Official Story)

(The Unofficial Story)

LIBERAL LEGALISM

CRITICAL LEGALISM

\begin{tabular}{l|l|l|}
\hline $\begin{array}{l}\text { VALUE (or } \\
\text { Longing): }\end{array}$ & Autonomy & $\begin{array}{l}\text { Connection; } \\
\text { Community }\end{array}$ \\
\hline HARM (or & Annihilation; & $\begin{array}{l}\text { Alienation; } \\
\text { Isolation }\end{array}$ \\
\hline
\end{tabular}

Let me now turn to feminist theory. Although the legal academy is for the most part unaware of it, modern feminist theory is as fundamentally divided as legal theory. One way to characterize the conflict-the increasingly standard way to characterize the conflict-is that while most modern feminists agree that women are different from men and agree on the importance of the difference, feminists differ over which differences between men and women are most vital. According to one group of feminists, sometimes called "cultural feminists," the important difference between men and women is that women raise children and men don't. According to a second group of feminists, now called "radical feminists," the important difference between men and women is that women get fucked and men fuck: "women," definitionally, are "those from whom sex is taken," just as workers, definitionally, are those from whom labor is taken. Another way to put the difference is in political terms. Cultural feminists appear somewhat more "moderate" when compared with the traditional culture: from a mainstream non-feminist perspective, cultural feminists appear to celebrate many of the same feminine traits that the traditional culture has stereotypically celebrated. Radical feminists, again from a mainstream perspective, appear more separatist, and, in contrast with standard political debate, more alarming. They also appear to be more "political" in a sense which perfectly parallels the critical theory-liberal theory split described above: radical feminists appear to be more attuned to power disparities between men and women than are cultural feminists.

I think this traditional characterization is wrong on two counts. First, cultural feminists no less than radical feminists are well aware of women's powerlessness vis-a-vis men, and second, radical feminism, as I will later argue, is as centrally concerned with pregnancy as it is with intercourse. But again, instead of arguing against this traditional characterization of the divide between radical and cultural feminism, I want to provide an alternative. $\mathrm{My}$ alternative characterization structurally (although not substantively) parallels the characterization of the difference between lib- 
eral and critical legalism. Underlying both radical and cultural feminism is a conception of women's existential state that is grounded in women's potential for physical, material connection to human life, just as underlying both liberal and critical legalism is a conception of men's existential state that is grounded in the inevitability of men's physical separation from the species. I will call the shared conception of women's existential lives the "connection thesis." The divisions between radical and cultural feminism stem from divergent accounts of the subjectivity of the potential for connection, just as what divides liberal from critical legal theory are divergent accounts of the subjectivity of the inevitability of separation.

The "connection thesis" is simply this: Women are actually or potentially materially connected to other human life. Men aren't. This material fact has existential consequences. While it may be true for men that the individual is "epistemologically and morally prior to the collectivity," it is not true for women. The potential for material connection with the other defines women's subjective, phenomenological and existential state, just as surely as the inevitability of material separation from the other defines men's existential state. Our potential for material connection engenders pleasures and pains, values and dangers, and attractions and fears, which are entirely different from those which follow, for men, from the necessity of separation. Indeed, it is the rediscovery of the multitude of implications from this material difference between men and women which has enlivened (and divided) both cultural and radical feminism in this decade (and it is those discoveries which have distinguished both radical and cultural feminism from liberal feminism). As Carol Gilligan notes, this development is somewhat paradoxical: during the same decade that liberal feminist political activists and lawyers pressed for equal (meaning same) treatment by the law, feminist theorists in non-legal disciplines rediscovered women's differences from men. ${ }^{13}$ Thus, what unifies radical and cultural feminist theory (and what distinguishes both from liberal feminism) is the discovery, or rediscovery, of the importance of women's fundamental material difference from men. As we shall see, neither radical feminists nor cultural feminists are entirely explicit in their embrace of the connection thesis. But both groups, implicitly if not explicitly, adhere to some version of it.

If both cultural and radical feminists hold some version of the

13 Carol Gilligan, In a Different Voice 6-8 (1982). 
connection thesis, then one way of understanding the issues that divide radical and cultural feminists, different from the standard account given above, is that while radical and cultural feminists agree that women's lives are distinctive in their potential for material connection to others, they provide sharply contrasting accounts of the subjective experience of the material and existential state of connection. According to cultural feminist accounts of women's subjectivity, women value intimacy, develop a capacity for nurturance, and an ethic of care for the "other" with which we are connected, just as we learn to dread and fear separation from the other. Radical feminists tell a very different story. According to radical feminism, women's connection with the "other" is above all else invasive and intrusive: women's potential for material "connection" invites invasion into the physical integrity of our bodies, and intrusion into the existential integrity of our lives. Although women may "officially" value the intimacy of connection, we "unofficially" dread the intrusion it inevitably entails, and long for the individuation and independence that deliverance from that state of connection would permit. Paralleling the structure above, I will call these two descriptions feminism's official and unofficial stories of women's subjective experience of physical connection.

In large part due to the phenomenal success of Carol Gilligan's book In a Different Voice, cultural feminism may be the most familiar of these two feminist strands, and for that reason alone, I call it feminism's "official story." "Cultural feminism" (in this country and among academics) is in large part defined by Gilligan's book. Defined as such, cultural feminism begins not with a commitment to the "material" version of the connection thesis (as outlined above), but rather, with a commitment to its more observable existential and psychological consequences. Thus limited, we can put the cultural feminist point this way: women have a "sense" of existential "connection" to other human life which men do not. That sense of connection in turn entails a way of learning, a path of moral development, an aesthetic sense, and a view of the world and of one's place within it which sharply contrasts with men's. To reverse Sandel's formulation, for women, connection is "prior," both epistemologically and, therefore, morally, to the individual. One cultural feminist-Suzanna Sherry-calls this women's view of the world a "feminine" rather than "feminist" perspective. She summarizes the "feminine perspective" in this way:

[T] he feminine perspective views individuals primarily as interconnected members of a community. Nancy Chodorow and Carol Gilligan, in groundbreaking studies on the development 
of self and morality, have concluded that women tend to have a more intersubjective sense of self than men and that the feminine perspective is therefore more other-directed .... The essential difference between the male and female perspectives [is that] . . . "the basic feminine sense of self is connected to the world, the basic masculine sense of self is separate." Women thus tend to see others as extensions of themselves rather than as outsiders or competitors. ${ }^{14}$

Why are men and women different in this essential way? The cultural feminist explanation for women's heightened sense of connection is that women are more "connected" to life than are men because it is women who are the primary caretakers of young children. A female child develops her sense of identity as "continuous" with her caretaker's, while a young boy develops a sense of identity that is distinguished from his caretaker's. Because of the gender alignment of mothers and female children, young girls "fuse" their growing sense of identity with a sense of sameness with and attachment to the other, while because of the gender distinction between mothers and male children, young boys "fuse" their growing sense of identity with a sense of difference and separation from the other. This turns out to have truly extraordinary and far reaching consequences, for both cognitive and moral development. Nancy Chodorow explains:

[This means that] [g]irls emerge from this period with a basis for "empathy" built into their primary definition of self in a way that boys do not .... [G]irls come to experience themselves as less differentiated than boys, as more continuous with and related to the external object-world and as differently oriented to their inner object-world as well.1.

Women are therefore capable of a degree of physical as well as psychic intimacy with the other which greatly exceeds men's capacity. Carol Gilligan finds that:

The fusion of identity and intimacy ... [is] clearly articulated ... in [women's] . . . self-descriptions. In response to the request to describe themselves, ... . women describe a relationship, depicting their identity in the connection of future mother, present wife, adopted child, or past lover. Similarly,

14 Suzanna Sherry, Civic Virtue and the Feminine Voice in Constitutional Adjudication, 72 Va.L.Rev. 543, 584-85 (1986)(citations omitted)(emphasis added).

15 Nancy Chodorow, The Reproduction of Mothering 167 (1978). 
the standard of moral judgement that informs their assessment of self is a standard of relationship, an ethic of nurturance, responsibility, and care ... [In] women's descriptions, identity is defined in a context of relationship and judged by a standard of responsibility and care. Similarly, morality is seen by these women as arising from the experience of connection and conceived as a problem of inclusion rather than one of balancing claims. ${ }^{16}$

One of Gilligan's subjects, Claire, eloquently expresses her subjective sense of epistemological, moral, and psychological connection:

By yourself, there is little sense to things. It is like the sound of one hand clapping, the sound of one man or one woman, there is something lacking. It is the collective that is important to me, and that collective is based on certain guiding principles, one of which is that everybody belongs to it and that you all come from it. You have to love someone else, because while you may not like them, you are inseparable from them. In a way, it is like loving your right hand. They are part of you; that other person is part of that giant collection of people that you are connected to. ${ }^{17}$

Thus, according to Gilligan (and her subjects), women view themselves as fundamentally connected to, not separate from, the rest of life. This difference permeates virtually every aspect of our lives. According to the vast literature on difference now being developed by cultural feminists, women's cognitive development, literary sensibility, aesthetic taste, and psychological development, no less than our anatomy, are all fundamentally different from men's, and are different in the same way: unlike men, we view ourselves as connected to, not separate from, the other. As a consequence, women's ways of knowing are more "integrative" than men's; women's aesthetic and critical sense is "embroidered" rather than "laddered;" women's psychological development remains within the sphere of "attachment" rather than "individuation."

The most significant aspect of our difference, though, is surely the moral difference. According to cultural feminism, women are more nurturant, caring, loving and responsible to others than are men. This capacity for nurturance and care dictates the moral

16 Gilligan, In a Different Voice at 159-60 (cited in note 13).

17 Id. at 160. 
terms in which women, distinctively, construct social relations: women view the morality of actions against a standard of responsibility to others, rather than against a standard of rights and autonomy from others. As Gilligan puts it:

The moral imperative ... [for] women is an injunction to care, a responsibility to discern and alleviate the "real and recognizable trouble" of this world. For men, the moral imperative appears rather as an injunction to respect the rights of others and thus to protect from interference the rights to life and self-fulfillment. ${ }^{18}$

Cultural feminists, to their credit, have reidentified these differences as women's strengths, rather than women's weaknesses. Cultural feminism does not simply identify women's differences-patriarchy too insists on women's differences-it celebrates them. Women's art, women's craft, women's narrative capacity, women's critical eye, women's ways of knowing, and women's heart, are all, for the cultural feminist, redefined as things to celebrate. Quilting, cultural feminism insists, is not just something women do; it is art, and should be recognized as such. Integrative knowledge is not a confused and failed attempt to come to grips with the elementary rules of deductive logic; it is a way of knowledge and should be recognized as such. Women's distinctive aesthetic sense is as valid as men's. Most vital, however, for cultural feminism is the claim that intimacy is not just something women $d o$, it is something human beings ought to do. Intimacy is a source of value, not a private hobby. It is morality, not habit.

To pursue my structural analogy to masculine legal theory, then, intimacy and the ethic of care constitute the entailed values of the existential state of connection with others, just as autonomy and freedom constitute the entailed values of the existential state of separation from others for men. Because women are fundamentally connected to other human life, women value and enjoy intimacy with others (just as because men are fundamentally separate from other human life men value and enjoy autonomy). Because women are connected with the rest of human life, intimacy with the "other" comes naturally. Caring, nurturance, and an ethic of love and responsibility for life is second nature. Autonomy, or freedom from the other constitutes a value for men because it reflects an existential state of being: separate. Intimacy is a value for women because it reflects an existentially connected state of being. 
Intimacy, the capacity for nurturance and the ethic of care constitute what we might call the "up side" of the subjective experience of connection. It's all good. Intimacy feels good, nurturance is good, and caring for others morally is good. But there's a "down side" to the subjective experience of connection. There's danger, harm, and fear entailed by the state of connection as well as value. Whereas men fear annihilation from the separate other (and consequently have trouble achieving intimacy), women fear separation from the connected other (and consequently have trouble achieving independence). Gilligan makes the point succinctly: "Since masculinity is defined through separation while femininity is defined through attachment, male gender identity is threatened by intimacy while female gender identity is threatened by separation." 19 Separation, then, might be regarded as the official harm of cultural feminism. When a separate self must be asserted, women have trouble asserting it. Women's separation from the other in adult life, and the tension between that separation and our fundamental state of connection, is felt most acutely when a woman must make choices, and when she must speak the truth. It is at those times that separation and individuation are at a premium. Gilligan explains:

Since women, however, define their identity through relationships of intimacy and care, the moral problems that they encounter pertain to issues of a different sort. When relationships are secured by masking desire and conflict is avoided by equivocation, then confusion arises about the locus of responsibility and truth. [Mary] McCarthy, describing her 'representation' to her grandparents, explains:

Whatever I told them was usually so blurred and glossed, in the effort to meet their approval . . . that except when answering a direct question, I hardly knew whether what I was saying was true or false. I really tried, or so I thought, to avoid lying, but it seemed to me that they forced it on me by the difference in their vision of things, so that I was always transposing reality for them into terms they could understand. To keep matters straight with my conscience, I shrank, whenever possible from the lie absolute, just as, from a sense of precaution, I shrank from the plain truth.

10 Id. at 8. 
The critical experience then becomes not intimacy but choice, creating an encounter with self that clarifies the understanding of responsibility and truth. ${ }^{20}$

Separation, and the fear of separation, can lead to real harm, especially in later life. In her final chapter, Gilligan elaborates:

[B]ecause women's sense of integrity appears to be entwined with an ethic of care, so that to see themselves as women is to see themselves in a relationship of connection, the major transitions in women's lives would seem to involve changes in the understanding and activities of care. Certainly the shift from childhood to adulthood witnesses a major redefinition of care. . . .

In the same vein, however, the events of mid-life--the menopause and changes in family and work-can alter a woman's activities of care in ways that affect her sense of herself. If mid-life brings an end to relationships, to the sense of connection on which she relies, as well as to the activities of care through which she judges her worth, then the mourning that accompanies all life transitions can give way to the melancholia of self-deprecation and despair. ${ }^{21}$

Now, while Gilligan is undoubtedly explaining a real experiential phenomenon-I don't know of any woman who hasn't recognized herself somewhere in this book-her material explanation of that phenomenon is incomplete. Which is not to say it isn't true: It seems quite plausible that women are more psychically connected to others in just the way Gilligan describes and for just the reason she expounds. Mothers raise children, and as a consequence girls, and not boys, think of themselves as continuous with, rather than separate from, that first all-important "other"-the mother. But this psychological and developmental explanation just raises-it does not answer-the background material question: why do women, rather than men, raise, nurture, and cook for children? What is the cause of this difference?

Although Gilligan doesn't address the issue, other cultural feminists have, and their explanations converge, I believe, implicitly if not explicitly, on a material, or mixed material-cultural, and not just a cultural answer: women raise children-and hence raise girls who are more connected and nurturant, and therefore more

20 Id. at 164 (emphasis added).

21 Id. at 171. 
likely to be nurturant caretakers themselves-because it is women who bear children. Women are not inclined to abandon an infant they've carried for nine months and then delivered. If so, then women are ultimately more "connected"-psychically, emotionally, and morally - to other human beings because women, as children were raised by women and women raise children because women, uniquely, are physically and materially "connected" to those human beings when the human beings are fetuses and then infants. Women are more empathic to the lives of others because women are physically tied to the lives of others in a way which men are not. Women's moral voice is one of responsibility, duty and care for others because women's material circumstance is one of responsibility, duty and care for those who are first physically attached, then physically dependent, and then emotionally interdependent. Women think in terms of the needs of others rather than the rights of others because women materially, and then physically, and then psychically, provide for the needs of others. Lastly, women fear separation from the other rather than annihilation by him, and "count" it as a harm, because women experience the "separating" pain of childbirth and more deeply feel the pain of the maturation and departure of adult children.

Although this material explanation of women's difference now overtly dominates at least some forms of French cultural feminism, it still plays a largely implicit, rather than explicit role in United States cultural feminism, although that status is changing. There are several reasons for the reluctance of American cultural feminists to explicitly embrace a material version of the connection thesis. The first is totally external to feminism, and is, rather, internal to the academic community for which Gilligan's book was written and in which it was received. It is an academic allegiance to empirical rather than phenomenological explanations of social phenomena. Material explanations require a willingness to engage in a form of speculative inquiry which is contrary to now dominant academic modes of proof.

The second, and I believe major, reason for the resistance to material explanations of women's difference in American feminism is primarily strategic: American feminists of all stripes are wary of identifying the material fact of pregnancy as the root of moral, aesthetic, and cognitive difference, because, as liberal feminist and law professor Wendy Williams correctly notes, "most of the disadvantages imposed on women, in the workforce and elsewhere, derive from this central reality of the capacity of women to become pregnant and the real and supposed implications of this real- 
ity."22 The response to this "central reality" among American liberal feminists and American feminist lawyers has been to deny or minimize the importance of the pregnancy difference, thus making men and women more "alike," so as to force the legal system to treat men and women similarly.

Although a review of the history of liberal feminism is well beyond the scope of this essay, suffice it to say that there is a growing awareness amongst even liberal feminist legal theorists that this strategy has to some extent backfired. It has become increasingly clear that feminists must attack the burdens of pregnancy and its attendant differences, rather than denying the uniqueness of pregnancy. Thus, in a liberal feminist essay which for the most part rigorously attacks the pregnancy difference as "stereotyped" and false, Lucinda Finley in one paragraph acknowledges, and even commits herself to, a radically different point of view:

Permeating and sustaining each of these assumptions is the view that pregnancy is unique-that it affects only women and it is like no other human condition in its immediate physical effects, significance, and consequences. This fundamental assumption of uniqueness cannot easily be disputed, and it is not likely soon to wither away. Many women and men of a wide variety of political outlooks wish not to dispute pregnancy's uniqueness, but to celebrate it. . . . I sense that we will have lost something very fundamentally human in . . . a world of no "real" differences. My sense of loss stems from a feeling that I as a woman want to be able to revel in the joy and virtually mystical specialness of having a baby. What I do not want is to be punished for this wonderful gift at the same time. My feeling that something will be missing in this ideal androgynous world also comes from a fear that it rests on a vision of equality that says we can all be equal if we just strip away all our differences. Life in such a world would be boring, impoverished and unenriching .... The problem is not the uniqueness of something like pregnancy, but the view that our legal system has adopted towards "special" human qualities, particularly qualities that are special because they are inherently female in the sense that they cannot be experienced by a male. ${ }^{23}$

22 Discrimination on the Basis of Pregnancy, 1977, Hearings on S. 995 Before the Subcommittee on Labor of the Senate Committee on Human Resources, 95th Cong., 1st Sess. 123 (1977)(remarks of Professor Wendy Williams)(emphasis added).

${ }^{23}$ Lucinda M. Finley, Transcending Equality Theory: A Way Out of the Maternity and 
Outside of the legal community, however, there is less reluctance among even U.S. cultural feminists to embrace material explanations both of women's moral distinctiveness and political oppression. Let me mention just three examples, each from different disciplines. First, poet and scholar Adrienne Rich, who has surely done more than any other American feminist to lay bare the issues surrounding mandatory motherhood within conditions of patriarchy, briefly suggests the centrality of motherhood and the physicality of pregnancy to women's lives, to women's existential sense of connection, and ultimately of course to feminism:

I have seen massive sculpturelike weavings, of jute, hemp, and wool, in which many varicolored strands are quickly visible like vines or striations; but when you come closer and try to touch this or that strand, your hand enters a dense, bristling mesh, thick with knotted and twisted filaments, some harsh and rough to the fingers, others surprisingly silky and strong. In . . . thinking about motherhood . . . , I have felt a similar sensation, of elemental exploration and of complex discovery .... For motherhood is the great mesh in which all human relations are entangled, in which lurk our most elemental assumptions about love and power.

If we speak of motherhood at all, we are inevitably speaking of something far more than the relationship of a woman with her children. And even this relationship has been shaped long before the first child's birth. All women are daughters of women-is this an obvious, a simple-minded statement? or does it reach through the layers of the weaving to inner chambers only now beginning to be explored by women? It has been suggested by Margaret Mead that possibly a deep chemical affinity exists, of which we as yet know nothing, between the body of the mother and her still unborn female child. It has been affirmed by Nancy Chodorow, that through the intense mother-daughter relationship women come into a deep and richer inner life than men, and, even when heterosexual, tend to be more deeply attached to women than to men, and more capable than men of relationship . . . .

[F]eminist artists, historians, anthropologists have been the first to show concern and respect for the crafts of the midwives and grandmothers, the anonymous work of women's

the Workplace Debate, 86 Colum.L.Rev. 1118, $1139-40$ (1986)(citations omitted)(emphasis added). 
hands, the oral culture of women sitting in the kitchens, the traditional arts and remedies passed on from mother to daughter, the female culture never granted the reverence accorded to "high art." . . . And so we can both take pride in all that women have done for "love"-including the resourceful, heroic coping of ordinary women everywhere-and also ask "Why should women, and women only, work for love only?"24

Marilyn French has also begun to bring an overtly material explanation both of women's "difference" and of women's oppression out of the background and into the forefront of American cultural feminism. Women have a different moral voice, French argues, because women are fundamentally committed to the preservation and survival of life, while men are committed to the goal of transcendence. Although French insists, correctly, that this existential difference is in no sense biologically mandated (men could become more nurturant and women could become more independent), it is nevertheless biologically grounded: it reflects natural and material facts, and reflects our natural and pre-legal history. Women are tied to nature and the life of the other, French argues, while men are fearful of nature and seek to transcend it rather than preserve it. It is this material reality which entails women's existential connection:

Women and men-in general-have different moralities because they have different goals. Male morals are designed to permit male transcendence. Life-that mass of breathing flesh, sweating pores, darting sensation, uncontrollable being-is rooted in nature, in the fetid swamp, the foul murk into which manufactured nature-cities-seems always about to sink. Above these, stark, pure, beyond the pull of heart or genitals, soar a rigid set of principles, rules, taboos. To prove his full manhood . . . a man must cleave to these and abandon the other, which is the realm of woman ....

Female morals are designed to permit survival. Life is the highest good . . . : not necessarily one's personal life, but life itself, of plants and animals and humans, the community, the tribe, the family, the children ....

Female morals foster survival: which means they foster those elements, both material and immaterial, that are necessary to life. Women grow much of the world's food, and every-

${ }^{24}$ Adrienne Rich, On Lies, Secrets, and Silence 260-63 (1979)(citation omitted)(emphasis added). 
where women prepare food for those they live with. They do this because they are expected to, because they expect to, because they want to . . . . It is rewarded by the well-being of those fed. This is true. ${ }^{25}$

French ties this difference to pre-legal and pre-patriarchal history:

The fact that women from the first took responsibility for the young, feeding and teaching and protecting them, probably led by analogy to their taking responsibility for feeding the entire group. Female animals take responsibility for creating and finding shelter, making nests, for their young and themselves; early women continued this activity, building shelters both temporary and permanent. In many societies women still perform this task. The first feeding of the young from women's bodies may have led by analogy to responsibility for other forms of feeding-to grinding and cooking the vegetables they had gathered. Male responsibility was far more limited: among many groups even today, men care for themselves-they gather for themselves, make tools for themselves-and contribute minimally to the needs of the community. ${ }^{28}$

French also ties women's reproductive function to the cause of male contempt for women and ultimately to patriarchy itself; indeed, that men's dread of, fear of, and contempt for women's lifegiving reproductive power is the root cause of patriarchy is perhaps the central thesis of Beyond Power. In the final chapter, however, French suggests an implication of women's reproductive difference that goes beyond the causal explanation of patriarchy, and effects a subtle but important variation on Gilligan's thesis. The experience of being cared for as an infant, French suggests, is the root of the ethic of care celebrated by cultural feminists. Women, of course, do the caring, both before birth and immediately after it, but we have all had the experience of being cared for. We have all, that is, women as well as men, had the experience of "connection." That experience of being cared for is the cause of the different voice-presently, but by no means inevitably, women's voice-this time identified as a "feminist vision" rather than a "feminine perspective":

Feminism does not offer a fixed program or dogma, a new Law

2s Marilyn French, Beyond Power 482-83 (1985).

${ }^{26}$ Id. at $40-41$ (first emphasis added)(second emphasis in original). 
for the future, but it does offer a new vision of human nature, reality, and sociopolitical arrangement.

The vision entertained by many feminists, and the vision that informs this book, is of a humanity whose first experience-even before birth as well as immediately after it-is of being shared with, nurtured, cared for. We can, in a kind of shorthand, call this experience love, and for some infants the experience may be one of absolute love. For many it is a sharing and devotion mixed with resentment and hostility; nevertheless, the sharing is more important, for those who are not given to do not survive. Thus, those of us who do survive were shared with and nurtured sufficiently.

This early experience of being fed, held, warmed, protected, is one of ecstasy; . . . we seek out such experiences in our later life. In addition, experiencing nurturing teaches us all, men as well as women, how to nurture others in turn .... A morality ... that is based on human experience and need, rather than on the denial of human experience and need, would reflect this order. Nurturing qualities would be central, primary; education in limitation would be secondary in time and importance. ${ }^{27}$

Similarly, and finally, in Caring: A Feminine Approach to Ethics and Moral Education, ${ }^{28}$ Stanford philosopher and cultural feminist Nel Noddings endorses a biological and material explanation of women's different moral voice:

[C]learly, mothering and caring are deeply related. Several contemporary writers have raised a question that seems odd at first glance: Why is it that women in our society do the mothering? . . . . The biological view holds that women, having given birth and entered lactation, are naturally nurturant toward their infants. The socialization view denies arguments for nature, instinct, and natural nurturance and insists that mothering is a role-something learned. Finally, the psychological view suggested by Nancy Chodorow holds that the tendency for girls to want to mother, and to actually engage in mothering, is the result of deep psychological processes established in close and special relationships with their own mothers.

The socialization view, as an explanatory theory, seems

${ }^{28} \mathrm{Nel}$ Noddings, Caring (1984). 
nonsense. We are not nearly so successful at socializing people into roles as we are at reproducing mothering in women. Mothering is not a role but a relationship. The psychological view, however, seems very strong. . . . One difficulty [with it] is that those endorsing psychological views have felt the need to set aside or minimize biological arguments. It is true that a woman's natural inclination to mother a newborn does not explain why she continues to mother a child into adolescence or why she mothers other people's half-grown children. But it may well be that a completely adequate theory will have to embrace both biological and psychological factors. ${ }^{2 \theta}$

Whether we embrace a material or a purely developmental explanation of women's heightened connection with the other, however, the "story" of women's relationship with the other as told by cultural feminists contrast in virtually every particular with the story of men's relationship to the other as told by liberals. First, men, according to the Hobbesian account, are by nature equal. "Nature hath made men so equall, in the faculties of body, and mind; as that though there bee found one man sometimes manifestly stronger in body . . . ; yet when all is reckoned together, the difference between man, and man, is not so considerable, as that one man can thereupon claim to himselfe any benefit. . . . [T] weakest has strength enough to kill the strongest. . . ."30 Women, by contrast, are not "equal" in strength to the most important "other" they encounter: the fetus and then the newborn child. Rather, the fetus and the woman and later the infant and the mother occupy what might be called a natural, hierarchical web of inequality, not a natural state of equality: whereas men may be "by nature equal" women are "by nature stronger" than those who are most important to them and most dependent upon them. The natural physical equality between self and other on which Hobbes insists is simply untrue of women's natural state. Second, according to Hobbes, "men" are naturally inclined to aggress against those they perceive as the vulnerable other. Again, women are not: infants are dependent upon mothers and vulnerable to them, yet the natural mother does not aggress against her child, she breastfeeds her. And lastly, men respond to the vulnerability of natural equality by developing a morality and a civil state that demand respect for the equality, rights and freedom of the other. Women

20 Id. at 128

so Hobbes, Leviathan at 183 (cited in note 7). 
do not. Women respond to their natural state of inequality by developing a morality of nurturance that is responsible for the wellbeing of the dependent, and an ethic of care that responds to the greater needs of the weak. Men respond to the natural state of equality with an ethic of autonomy and rights. Women respond to the natural state of inequality with an ethic of responsibility and care.

We might summarize cultural feminism in this way: women's potential for a material connection to life entails (either directly, as I have argued, or indirectly, through the reproduction of mothering) an experiential and psychological sense of connection with other human life, which in turn entails both women's concept of value, and women's concept of harm. Women's concept of value revolves not around the axis of autonomy, individuality, justice and rights, as does men's, but instead around the axis of intimacy, nurturance, community, responsibility and care. For women, the creation of value, and the living of a good life, therefore depend upon relational, contextual, nurturant and affective responses to the needs of those who are dependent and weak, while for men the creation of value, and the living of the good life, depend upon the ability to respect the rights of independent co-equals, and the deductive, cognitive ability to infer from those rights rules for safe living. Women's concept of harm revolves not around a fear of annihilation by the other but around a fear of separation and isolation from the human community on which she depends, and which is dependent upon her. If, as I have suggested, cultural feminism is our dominant feminist dogma, then this account of the nature of women's lives constitutes the "official text" of feminism, just as liberal legalism constitutes the official text of legalism.

These two "official stories" sharply contrast. Whereas according to liberal legalism, men value autonomy from the other and fear annihilation by him, women, according to cultural feminism, value intimacy with the other and fear separation from her. Women's sense of connection with others determines our special competencies and special vulnerabilities, just as men's sense of separation from others determines theirs. Women value and have a special competency for intimacy, nurturance, and relational thinking, and a special vulnerability to and fear of isolation, separation from the other, and abandonment, just as men value and have a special competency for autonomy, and a special vulnerability to and fear of annihilation.

Against the cultural feminist backdrop, the story that radical feminists tell of women's invaded, violated lives is "subterranean" 
in the same sense that, against the backdrop of liberal legalism, the story critical legal theorists tell of men's alienation and isolation from others is subterranean. According to radical feminism, women's connection to others is the source of women's misery, not a source of value worth celebrating. For cultural feminists, women's connectedness to the other (whether material or cultural) is the source, the heart, the root, and the cause of women's different morality, different voice, different "ways of knowing," different genius, different capacity for care, and different ability to nurture. For radical feminists, that same potential for connection-experienced materially in intercourse and pregnancy, but experienced existentially in all spheres of life-is the source of women's debasement, powerlessness, subjugation, and misery. It is the cause of our pain, and the reason for our stunted lives. Invasion and intrusion, rather than intimacy, nurturance and care, is the "unofficial" story of women's subjective experience of connection.

Thus, modern radical feminism is unified among other things by its insistence on the invasive, oppressive, destructive implications of women's material and existential connection to the other. So defined, radical feminism (of modern times) begins not with the eighties critique of heterosexuality, but rather in the late sixties, with Shulamith Firestone's angry and eloquent denunciation of the oppressive consequences for women of the physical condition of pregnancy. Firestone's assessment of the importance and distinctiveness of women's reproductive role parallels Marilyn French's. Both view women's physical connection with nature and with the other as in some sense the "cause" of patriarchy. But their analyses of the chain of causation sharply contrast. For French, women's reproductive role-the paradigmatic experience of physical connection to nature, to life and to the other, and thus the core of women's moral difference-is also the cause of patriarchy, primarily because of men's fear of and contempt for nature. Firestone has a radically different view. Pregnancy is indeed the paradigmatic experience of physical connection, and it is indeed the core of women's difference, but according to Firestone, it is for that reason alone the cause of women's oppression. Male contempt has nothing (at first) to do with it. Pregnancy itself, independent of male contempt, is invasive, dangerous and oppressive; it is an assault on the physical integrity and privacy of the body. For Firestone, the strategic implication of this is both clear and clearly material. The technological separation of reproduction from the female body is 
the necessary condition for women's liberation. ${ }^{31}$

In a moment, I will turn to heterosexual intercourse, for it is intercourse, rather than pregnancy, which consumes the attention of the modern radical feminism of our decade. But before doing so it's worth recognizing that the original radical feminist case for reproductive freedom did not turn on rights of "privacy" (either of the doctor-patient relationship, or of the marriage, or of the family), or rights to "equal protection," or rights to be free of "discrimination." It did not turn on rights at all. Rather, the original feminist argument for reproductive freedom turned on the definitive radical feminist insight that pregnancy-the invasion of the body by the other to which women are distinctively vulnerable-is an injury and ought to be treated as such. Pregnancy connects us with life, as the cultural feminist insists, but that connection is not something to celebrate; it is that very connection that hurts us. This argument, as I will argue later, is radically incommensurate with liberal legal ideology. There's no legal category that fits it. But it is nevertheless the radical argument-that pregnancy is a dangerous, psychically consuming, existentially intrusive, and physically invasive assault upon the body which in turn leads to a dangerous, consuming, intrusive, invasive assault on the mother's self-identity-that best captures women's own sense of the injury and danger of pregnancy, whether or not it captures the law's sense of what an unwanted pregnancy involves, or why women should have the right to terminate it.

The radical feminist argument for reproductive freedom appears in legal argument only inadvertently or surreptitiously, but it does on occasion appear. It appeared most recently in the phenomenological descriptions of unwanted pregnancies collated in the Thornburgh amicus brief recently filed by the National Abortion Rights Action League ("NARAL"). ${ }^{32}$ The descriptions of pregnancy collated in that peculiarly non-legal legal document are filled with metaphors of invasion-metaphors, of course, because we lack the vocabulary to name these harms precisely. Those descriptions contrast sharply with the "joy" that cultural feminists celebrate in pregnancy, childbirth and child-raising. The invasion of the self by the other emerges as a source of oppression, not a

31 Shulamith Firestone, The Dialectic of Sex (1970).

${ }^{32}$ Amicus Brief for the National Abortion Rights Action League, et. al., Thornburgh v. American College of Obstetricians and Gynecologists, Nos. 84-495 and 84-1379 ("NARAL Amicus Brief")(on file at The University of Chicago Law Review). For the Supreme Court opinion, see 476 U.S. 747 (1986). 
source of moral value.

"During my pregnancy," one women explains, "I was treated like a baby machine-an incubator without feelings."3s "Then I got pregnant again," another woman writes,

This one would be only 13 months younger than the third child. I was faced with the unpleasant fact that I could not stop the babies from coming no matter what I did . . . . You cannot possibly know what it is like to be the helpless pawn of nature. I am a 71 year old widow. ${ }^{34}$

"Almost exactly a decade ago," writes another, "I learned I was pregnant. . . . I was sick in my heart and I thought I would kill myself. It was as if I had been told my body had been invaded with cancer. It seemed that very wrong."3s

One woman speaks directly, without metaphor: "On the ride home from the clinic, the relief was enormous. I felt happy for the first time in weeks. I had a future again. I had my body back."s6

According to these women's self-descriptions, when the unwanted baby arrives, the injury is again one of invasion, intrusion and limitation. The harm of an unwanted pregnancy is that the baby will elicit a surrender (not an end) of the mother's life. The fear of unwanted pregnancy is that one will lose control of one's individuated being (not that one will die). Thus, one woman writes, "I was like any other woman who had an unintended pregnancy, I was terrified and felt as though my life was out of my control." 37

This danger, and the fear of it, is gender-specific. It is a fear which grips women, distinctively, and it is a fear about which men, apparently, know practically nothing. Another woman writes:

I was furiously angry, dismayed, dismal, by turns. I could not justify an abortion on economic grounds, on grounds of insufficient competence or on any other of a multitude of what might be perceived as "legitimate" reasons. But I kept being struck by the ultimate unfairness of it all. I could not conceive of any event which would so profoundly impact upon any man. Surely my husband would experience some additional financial burden, and additional "fatherly" chores, but his

\footnotetext{
s3 NARAL Amicus Brief at 13 (emphasis added).

34 Id. at 19 (emphasis added).

ss Id at 28 (emphasis added).

so Id. at 29 (emphasis added).

37 Id. at 29.
} 
whole future plan was not hostage to this unchosen, undesired event. Basically his life would remain the same progression of ordered events as before. ${ }^{38}$

And another:

Being a mother is hard at any age but being a teenager makes it harder. . . . Things I may have wanted to do before getting pregnant, like college and a career are different now. Before I think about my dreams, I have to think about taking care of a baby. . . . I could be making plans for my future, but instead I'm making plans for my baby's future. ${ }^{39}$

Conversely, women who had abortions felt able to form their own destiny. One woman wrote: "Personally legal abortion allowed me the choice as a teenager living on a very poor Indian Reservation to finish growing up and make something of my life."40 And another:

I was not glad that I, was faced with an unwanted, unplanned pregnancy, however I am glad that I made the decision to have an abortion. The experience was a very positive one for me. It helped me learn that I am a person and I can make independent decisions. Had I not had the abortion I would have probably ended up a single mother struggling for survival and dealing with a child that I was not ready for. ${ }^{41}$

As noted above, radical feminism of the eighties has focused more on intercourse than on pregnancy. But this may represent less of a divergence than it first appears. From the point of view of the "connection thesis," what the radical feminists of the eighties find objectionable, invasive, and oppressive about heterosexual intercourse, is precisely what the radical feminists of the sixties found objectionable, invasive, and oppressive about pregnancy and motherhood. According to the eighties radical critique, intercourse, like pregnancy, blurs the physical boundary between self and other, and that blurring of boundaries between self and other constitutes a profound invasion of the self's physical integrity. That invasion-the "dissolving of boundaries"-is something to condemn, not celebrate. Andrea Dworkin explains:

Sexual intercourse is not intrinsically banal, though pop-cul- 
ture magazines like Esquire and Cosmopolitan would suggest that it is. It is intense, often desperate. The internal landscape is violent upheaval, a wild and ultimately cruel disregard of human individuality, . . . no respecter of boundaries. . . .

Sometimes, the skin comes off in sex. The people merge, skinless. The body loses its boundaries. . . . There is no physical distance, no self-consciousness, nothing withdrawn or private or alienated, no existence outside physical touch. The skin collapses as a boundary - it has no meaning ..... Instead, there is necessity, nothing else-being driven, physical immersion in "each other" but with no experience of "each other" as separate entities coming together. . . .

The skin is a line of demarcation, a periphery, the fence, the form, the shape, the first clue to identity in a society ... , and, in purely physical terms, the formal precondition for being human. It is a thin veil of matter separating the outside from the inside. . . The skin is separation, individuality, the basis for corporeal privacy, . . . . ${ }^{42}$

Women, distinctively, lose this "formal precondition for being human" and they lose it in intercourse:

A human being has a body that is inviolate; and when it is violated, it is abused. A woman has a body that is penetrated in intercourse: permeable, its corporeal solidness a lie. The discourse of male truth-literature, science, philosophy, pornography-calls that penetration violation. This it does with some consistency and some confidence. Violation is a synonym for intercourse. At the same time, the penetration is taken to be a use, not an abuse; a normal use; it is appropriate to enter her, to push into ("violate") the boundaries of her body. She is human, of course, but by a standard that does not include physical privacy. She is, in fact, human by a standard that precludes physical privacy, since to keep a man out altogether and for a lifetime is deviant in the extreme, a psychopathology, a repudiation of the way in which she is expected to manifest her humanity. ${ }^{43}$

Like pregnancy, then, intercourse is invasive, intrusive and violative, and like pregnancy it is therefore the cause of women's oppressed, invaded, intruded, violated, and debased lives. Dworkin

12 Andrea Dworkin, Intercourse 21-22 (1987)(emphasis added).

${ }^{43}$ Id. at 122. 
concludes:

This is nihilism; or this is truth. He has to push in past boundaries. There is the outline of a body, distinct, separate, its integrity an illusion, a tragic deception, because unseen there is a slit between the legs, and he has to push into it. There is never a real privacy of the body that can co-exist with intercourse: with being entered. The vagina itself is muscled and the muscles have to be pushed apart. The thrusting is persistent invasion. She is opened up, split down the center. She is occupied-physically, internally, in her privacy . . . .

She, a human being, is supposed to have a privacy that is absolute; except that she, a woman, has a hole between her legs that men can, must, do enter. This hole, her hole, is synonymous with entry. A man has an anus that can be entered, but his anus is not synonymous with entry. A woman has an anus that can be entered, but her anus is not synonymous with entry. The slit between her legs, so simple, so hidden-frankly, so innocent-for instance, to the child who looks with a mirror to see if it could be true-is there an entrance to her body down there? . . . - that slit which means entry into her-intercourse-appears to be the key to women's lower human status. By definition, .... she is intended to have a lesser privacy, a lesser integrity of the body, a lesser sense of self, . . . [and] this lesser privacy, this lesser integrity, this lesser self, establishes her lesser significance. ... She is defined by how she is made, that hole, which is synonymous with entry; and intercourse, the act fundamental to existence, has consequences to her being that may be intrinsic, not socially imposed. ${ }^{44}$

Although Dworkin herself does not draw the parallel, for both Dworkin and Firestone, women's potential for material connection with the other-whether through intercourse or pregnancy-constitutes an invasion upon our physical bodies, an intrusion upon our lives, and consequently an assault upon our existential freedom, whether or not it is also the root of our moral distinctiveness (the claim cultural feminism makes on behalf of pregnancy), or the hope of our liberation (the claim sexual liberationists make on behalf of sex). Both intercourse and pregnancy are literal, physical, material invasions and occupations of the

44 Id. at 122-23 (emphasis added on the words "and intercourse, the act," otherwise emphasis in original). 
body. The fetus, like the penis, literally occupies my body. In their extremes, of course, both unwanted heterosexual intercourse and unwanted pregnancy can be life threatening experiences of physical invasion. An unwanted fetus, no less than an unwanted penis, invades my body, violates my physical boundaries, occupies my body and can potentially destroy my sense of self. Although the culture does not recognize them as such, the physical and existential invasions occasioned by unwanted pregnancy and intercourse are real harms. They are events we should fear. They are events which any sane person should protect herself against. What unifies the radical feminism of the sixties and eighties is the argument that women's potential for material, physical connection with the other constitutes an invasion which is a very real harm causing very real damage, and which society ought to recognize as such.

The material, sporadic violation of a woman's body occasioned by pregnancy and intercourse implies an existential and pervasive violation of her privacy, integrity and life projects. According to radical feminists, women's longings for individuation, physical privacy, and independence go well beyond the desire to avoid the dangers of rape or unwanted pregnancy. Women also long for liberation from the oppression of intimacy (and its attendant values) which both cultural feminism and most women officially, and wrongly, overvalue. Intimacy, in short, is intrusive, even when it isn't life threatening (perhaps especially when it isn't life threatening). An unwanted pregnancy is disastrous, but even a wanted pregnancy and motherhood are intrusive. The child intrudes, just as the fetus invades.

Similarly, while unwanted heterosexual intercourse is disastrous, even wanted heterosexual intercourse is intrusive. The penis occupies the body and "divides the woman" internally, to use Andrea Dworkin's language, in consensual intercourse no less than in rape. It preempts, challenges, negates, and renders impossible the maintenance of physical integrity and the formation of a unified self. The deepest unofficial story of radical feminism may be that intimacy - the official value of cultural feminism-is itself oppressive. Women secretly, unofficially, and surreptitiously long for the very individuation that cultural feminism insists women fear: the freedom, the independence, the individuality, the sense of wholeness, the confidence, the self-esteem, and the security of identity which can only come from a life, a history, a path, a voice, a sexuality, a womb, and a body of one's own. Dworkin explains:

In the experience of intercourse, she loses the capacity for integrity because her body-the basis of privacy and freedom in 
the material world for all human beings-is entered and occupied; the boundaries of her physical body are-neutrally speaking-violated. What is taken from her in that act is not recoverable, and she spends her life-wanting, after all to have something-pretending that pleasure is in being reduced through intercourse to insignificance .... She learns to eroticize powerlessness and self-annihilation. The very boundaries of her own body become meaningless to her, and even worse, useless to her. The transgression of those boundaries comes to signify a sexually charged degradation into which she throws herself, having been told, convinced, that identity, for a female, is there-somewhere beyond privacy and selfrespect. ${ }^{45}$

Radical feminism, then, is unified by a particular description of the subjectivity of the material state of connection. According to that description, women dread intrusion and invasion, and long for an independent, individualized, separate identity. While women may indeed "officially" value intimacy, what women unofficially crave is physical privacy, physical integrity, and sexual celibacy-in a word, physical exclusivity. In the moral realm, women officially value contextual, relational, caring, moral thinking, but secretly wish that everyone would get the hell out of our lives so that we could pursue our own projects-we loathe the intrusion that intimacy entails. In the epistemological and moral realms, while women officially value community, the web, the spinning wheel, and the weave, we privately crave solitude, self-regard, selfesteem, linear thinking, legal rights, and principled thought.

The contrasting accounts of women's subjective lives that emerge from modern feminist theory's rediscovery of women's difference might be schematized in this way:

CULTURAL FEMINISM RADICAL FEMINISM

\begin{tabular}{l|l|l|}
\hline $\begin{array}{l}\text { VALUE, (or } \\
\text { Longing): }\end{array}$ & Intimacy & $\begin{array}{l}\text { Individuation } \\
\text { Integrity }\end{array}$ \\
\hline $\begin{array}{l}\text { HARM, (or } \\
\text { Dread): }\end{array}$ & Separation & $\begin{array}{l}\text { Invasion; } \\
\text { Intrusion }\end{array}$ \\
\hline
\end{tabular}

Finally, then, we can schematize the contrast between the description of the "human being" that emerges from modern legal 
theory, and the description of women that emerges from modern feminism:

THE OFFICIAL STORY

(Liberal legalism and cultural feminism)
THE UNOFFICIAL STORY

(Critical legalism and radical feminism)

\begin{tabular}{l|c|c||c|c}
\hline & Value & Harm & Longing & Dread \\
\hline $\begin{array}{l}\text { LEGAL THEORY } \\
\text { (human beings) }\end{array}$ & Autonomy & $\begin{array}{l}\text { Annihilation; } \\
\text { Frustration }\end{array}$ & $\begin{array}{l}\text { Attachment; } \\
\text { Connection }\end{array}$ & Alienation \\
\hline & & & & \\
\hline $\begin{array}{l}\text { FEMINIST THEORY } \\
\text { (women) }\end{array}$ & Intimacy & Separation & Individuation & $\begin{array}{l}\text { Invasion; } \\
\text { Intrusion }\end{array}$ \\
\hline
\end{tabular}

As the diagram reveals, the descriptions of the subjectivity of human existence told by feminist theory and legal theory contrast at every point. There is no overlap. First, and most obviously, the "official" descriptions of human beings' subjectivity and women's subjectivity contrast rather than compare. According to liberal theory, human beings respond aggressively to their natural state of relative physical equality. In response to the great dangers posed by their natural aggression, they abide by a sharply anti-naturalist morality of autonomy, rights, and individual spheres of freedom, which is intended to and to some extent does curb their natural aggression. They respect a civil state that enforces those rights against the most egregious breaches. The description of women's subjectivity told by cultural feminism is much the opposite. According to cultural feminism, women inhabit a realm of natural inequality. They are physically stronger than the fetus and the infant. Women respond to their natural inequality over the fetus and infant not with aggression, but with nurturance and care. That natural and nurturant response evolves into a naturalist moral ethic of care which is consistent with women's natural response. The substantive moralities consequent to these two stories, then, unsurprisingly, are also diametrically opposed. The autonomy that human beings value and the rights they need as a restriction on their natural hostility to the equal and separate other are in sharp contrast to the intimacy that women value, and the ethic of care that represents not a limitation upon, but an extension of, women's natural nurturant response to the dependent, connected other.

The subterranean descriptions of subjectivity that emerge from the unofficial stories of radical feminism and critical legalism also contrast rather than compare. According to the critical legalists, human beings respond to their natural state of physical sepa- 
rateness not with aggression, fear and mutual suspicion, as liberalism holds, but with longing. Men suffer from a perpetual dread of isolation and alienation and a fear of rejection, and harbor a craving for community, connection, and association. Women, by contrast, according to radical feminism, respond to their natural state of material connection to the other with a craving for individuation and a loathing for invasion. Just as clearly, the subterranean dread men have of alienation (according to critical legalism) contrasts sharply with the subterranean dread that women have of invasion and intrusion (according to radical feminism).

The responses of human beings and women to these subterranean desires also contrast in substance, although, interestingly, the responses are structurally similar. According to both critical legalism and radical feminism, human beings and women, respectively, for the most part deny the subterranean desires that permeate their lives. Instead, they collaborate, to some degree, in the official culture's elaborate attempt to deny while partially accommodating the intensity of those felt needs. Both do so for the same reason: both human beings and women deny their subterranean desires because of a fear-legitimately grounded-that the subterranean need, if asserted, will be met by either violence or rejection by the dominant culture. The dominant male culture condemns as aberrant the man who needs others, just as the dominant female culture condemns the woman who wants to exist apart from others. Thus, men deny their need for attachment and women deny their need for individuation. The mechanisms by which the two groups effect the denial are fundamentally opposed in substance, albeit structurally parallel. According to critical theory, human beings deny their need for attachment primarily through the distancing and individuating assertion of individual rights. It is the purpose and content of those rights to largely deny the human need for attachment and communion with the other. According to radical feminism, women deny their need for individuation through the "intimating" mechanisms of romance, sentiment, familial ideology, the mystique of motherhood, and commitment to the false claims of affective attachment. It is the purpose and content of romance and familial ideology to largely deny women's need for individuation, separation, and individual identity.

Somewhat less obviously, the "unofficial" description of subjectivity provided by each side is not simply the equivalent of the "official" description of the other, although they are often mistaken as such. The mistaken belief that they are is responsible, I think, for the widespread and confused claim that critical legal 
studies already is feminist because the critical scholars' description of subjectivity converges with the cultural feminists' description of subjectivity, and the less widespread but equally confused claim that radical feminism is "just" liberalism, for the parallel reason.

First, the subjectivity depicted by critical legalism-the craving for connection and the dread of alienation-is not the subjectivity depicted by cultural feminism-the capacity for intimacy, the ethic of care, and the fear of separation. It is not hard to see the basis for the confused claim that cultural feminism's depiction of feminine subjectivity mirrors critical conceptions of the subjective experience of masculinity, though. There are two reasons for this confused identification. First, as Duncan Kennedy correctly notes, liberalism is indeed the rhetoric of the status quo. The description of subjectivity upon which critical legalists insist-“"withdrawn selves" who cringe from autonomy and secretly crave community-contrasts sharply with the description of subjectivity endorsed by dominant, mainstream liberal ideology. The critics' description of subjective life is not well regarded by people in power, to put the point lightly. Indeed, it is somewhat despised. Vis-a-vis liberal ideology, it is truly radical. It is underground. Similarly, women and women's values, to put the point lightly, are underground, despised, opposed, or at best undervalued by people in power. Vis-a-vis feminism, cultural feminism may be "dominant," but vis-a-vis liberalism, cultural feminism is at least as deeply underground and disapproved as critical legalism, if not more so. Cultural feminism and critical legalism share the outsider's status.

Further, the potential for connection which women naturally have and which cultural feminism celebrates, is in a sense the goal of critical legalism's alienated hero. For that reason, perhaps, the critical description of subjectivity may be confusedly identified as feminist. Nevertheless, the identification is over-stated. Unger explains the human being's natural goal of connection, or "natural harmony" in this way:

In what sense and to what extent can . . . natural harmony be achieved by man? Take first the problem of reconciliation to the nonhuman world. The moral, artistic, and religious traditions of many cultures emphasize the persistence of men's desire to see themselves as members of a community of natural, and, above all, of living things.

Because of its sexual aspect, love helps man overcome the distinction between self and nature within his own person. As a conscious and indeterminate being, he is distinguished by 
his relative freedom from the instincts or natural inclinations. These inclinations are the natural element within him. Insofar as he undergoes them, he is a natural being; and, insofar as he is free from them, he is more than a natural being. The natural inclinations, like the drives for food and sex, appear as a tyrannical fate; they impose limits and demands on what consciousness can accomplish.

But in love, the union of persons, which represents an ideal of the relation between self and others, is consummated through the natural inclination of sex. It is not the case in love that the more a man is a natural being, the less is he distinctively human. On the contrary, the gap between mind and natural disposition is bridged. By satisfying the ideal of his relation with others and thereby becoming more human, he also becomes more completely natural. ${ }^{46}$

But Unger's explanation reveals the difference, not the sameness, between the intimacy women value and the "connection" that men seek. Women do not value love and intimacy because it "helps us overcome the distinction between self and nature." On the contrary, women value love and intimacy because they express the unity of self and nature within our own selves. More generally, women do not struggle toward connection with others, against what turn out to be insurmountable obstacles. Intimacy is not something which women fight to become capable of. We just do it. It is ridiculously easy. It is also, I suspect, qualitatively beyond the pale of male effort. The difference might be put pictorially: the intimacy women value is a sharing of intersubjective territory that preexists the effort made to identify it. The connection that I suspect men strive for does not preexist the effort, and it is not a sharing of space; at best it is an adjacency. Gilligan inadvertently sums the difference between the community critical legal studies insists that men surreptitiously seek, and the intimacy that cultural feminism insists that women value: "The discovery now being celebrated by men in mid-life of the importance of intimacy, relationships, and care is something that women have known from the beginning." 47

Similarly, the dread of alienation that (according to critical legal studies) permeates men's lives is not the same as the fear of isolation and separation from the other that characterizes women's

${ }^{47}$ Gilligan, In a Different Voice at 17 (cited in note 13). 
lives. The fear of separation, for women, is fundamental, physical, economic, empathic, and psychological, as well as psychic. Separation from one's infant will kill the infant to whom the mother has been physically and then psychically connected, and therefore a part of the mother will die as well; separation from one's community may have similarly life threatening consequences. The alienation men dread is not the fear that oneself or the one with whom one is in symbiosis will be threatened. The alienation that men dread is a sorrow over a fundamental, basic, "first" existential state of being. The longing to overcome alienation is a socially constructed reaction against the natural fact of individuation. More bluntly-love, for men, is an acquired skill; separation (and therefore autonomy) is what comes naturally. The separation that endangers women, by contrast, is what is socially constructed-attachment is natural. Separation, and the dread of it, is the response to the natural (and pleasant) state of connection.

Second, the description of women's subjective nature, aspirations, and fears drawn by radical feminism is not the same as the description of "human nature" employed by liberalism. It is not hard, however, to see the basis for this confusion. Both radical feminism and liberalism view the other as a danger to the self: liberalism identifies the other as a threat to autonomy and to life itself; radical feminism identifies the other as a threat to individuation and to physical integrity. It is hardly surprising, then, that radical feminists borrow heavily from liberalism's protective armor of rights and distance. From the radical feminist point of view, "liberal rights-talk," so disparaged by critical legalists, is just fine, and it would be even better if it protected women against the dangers that characterize their lives, as well as protecting men against the dangers that characterize their lives.

The structural similarity ends there, though. The invasion and intrusion that women dread from the penetrating and impregnating potential of the connected other is not the same as the annihilation and frustration by the separate other that men fear. Men's greatest fear is that of being wiped out-of being killed. The fear of sexual and fetal invasion and intrusion that permeates women's lives is not the fear of annihilation or frustration. The fear of sexual and fetal invasion is the fear of being occupied from within, not annihilated from without; of having one's self overcome, not ended; of having one's own physical and material life taken over by the pressing physical urgency of another, not ended by the conflicting interests of another; of being, in short, overtaken, occupied, displaced, and invaded, not killed. Furthermore, the intrusiveness 
of less damaging forms of intimacy-"wanted" intimacy-is not equivalent to the lesser form of annihilation liberalism recognizes: having one's ends frustrated by the conflicting ends of the other. I do not fear having my "ends" frustrated; I fear having my ends "displaced" before I even formulate them. I fear that I will be refused the right to be an "I" who fears. I fear that my ends will not be my own. I fear that the phrase "my ends" will prove to be (or already is) oxymoronic. I fear I will never feel the freedom, or have the space, to become an ends-making creature.

Similarly, the individuation prized by radical feminism is not the same as the autonomy liberalism heralds, although it may be a precondition of it. The "autonomy" praised by liberalism is one's right to pursue one's own ends. "Individuation," as understood by radical feminism, is the right to be the sort of creature who might have and then pursue one's "own" ends. Women's longing for individuation is a longing for a transcendent state of individuated being against that which is internally contrary, given, fundamental, and first. Autonomy is something which is natural to men's existential state and which the state might protect. Individuation, by contrast, is the material pre-condition of autonomy. Individuation is what you need to be before you can even begin to think about what you need to be free.

These, then, are the differences between the "human beings" assumed by legal theory and women, as their lives are now being articulated by feminist theory. The human being, according to legal theory, values autonomy and fears annihilation, while at the same time he subjectively dreads the alienation that his love of autonomy inevitably entails. Women, according to feminist theory, value intimacy and fear separation, while at the same time longing for the individuation which our fear of separation precludes, and dreading the invasion which our love of intimacy entails. The human being assumed or constituted by legal theory precludes the woman described by feminism.

\section{Fundamental Contradictions}

In Part Three of this article, I will explore the implications of the conclusion just offered-that the human being assumed by legal theory precludes the women described by feminism-for the development of feminist jurisprudence. Before doing so, however, I want to pursue the structural comparison of the descriptions of subjectivity offered by legal theory and feminist theory one step further. Both theories appear to offer internally contradictory descriptions of men and women's subjectivity respectively. The "off- 
cial story" of subjectivity proffered by liberal legalism conflicts with the account of the subjectivity of separation put forward by critical legal theory, just as the "official story" of cultural feminism conflicts with radical feminists' contrasting account of the subjectivity of connection. Neither cultural feminism nor liberal legalism have generated explanations of the apparently contradictory accounts of subjectivity offered by radical feminism and critical legalism, respectively. Both should do so. Radical feminism and critical legalism, however, have addressed the issue and at considerable length. I want now to explore those explanations, and try to improve on them.

One explanation of the divergence between official value and subjective life that appears in both radical feminist thought and in critical legal theory centers on the psychoanalytic concept of denial. A second explanation, which also appears in both critical legalism and radical feminism, centers on the Gramscian and Marxist concept of legitimation and apology. A possible third explanation of the same phenomenon, which appears in critical legal theory but not in feminism, centers on Duncan Kennedy's provocative notion of a "fundamental contradiction." I wish to endorse this third explanation, and suggest how it might fruitfully be applied to some of the contradictions that presently plague feminist theory. First, though, I will explore the first two explanations, and explain why I think they fail in both radical feminist theory and critical theory, although my focus will be on feminism.

The first explanation for the contradiction between official value and subjective life that recurs in both critical legal theory and in radical feminism centers on the psychoanalytic concept of "denial", and its political corollary, "collaboration." Thus, both Andrea Dworkin and Catharine MacKinnon (and numerous other radical feminists) have argued that the high regard in which women hold physical, heterosexual intimacy constitutes a form of denial, bad faith, and, ultimately, collaboration with patriarchy. Dworkin presents the argument in its greatest detail. Women claim to find intimacy in intercourse, Dworkin argues, because women must, after all, "have something." Women claim to enjoy intercourse (and mislabel it as "intimacy") because women have become "alienated from freedom" as a result of our fear of self-assertion. This fear is not groundless-it is based for the most part on all-too-accurate memories of either threatened or actual violent reactions to an attempted asserting of sexual independence. But it is nevertheless a form of cowardice. Women who claim to value heterosexual intimacy deny their desire for freedom because they fear 
a reenactment of a primary, and extremely painful experience of violent, sexual oppression. In a word, they collaborate:

There is the initial complicity, the acts of self-mutilation, selfdiminishing, self-reconstruction, until there is no self, only the diminished, mutilated reconstruction. It is all superficial and unimportant, except what it costs the human in her to do it: except for the fact that it is submissive, conforming, giving up an individuality that would withstand object status or defy it. Something happens inside; a human forgets freedom; a human learns obedience; a human, this time a woman, learns how to goose-step the female way. ... . So the act goes beyond complicity to collaboration; but collaboration requires a preparing of the ground, an undermining of values and vision and dignity, a sense of alienation from the worth of other human beings-and this alienation is fundamental to females who are objectified because they do not experience themselves as human beings. ... Being an object for a man means being alienated from other women-those like her in status, in inferiority, in sexual function. Collaboration by women with men to keep women civilly and sexually inferior has been one of the hallmarks of female subordination; we are ashamed when Freud notices it, but it is true. ${ }^{48}$

Critical theorist Peter Gabel has given a perfectly parallel explanation of the attraction of autonomous, rights-focused, individuated liberal values in spite of the acutely painful longing for connection which in fact permeates men's lives. Gabel's argument structurally compares with Dworkin's, although it contrasts with it substantively. Thus, whereas Dworkin argues that women deny their desire for freedom, and distance themselves from it through a false commitment to intimacy, Gabel argues that human beings deny their craving for attachment with the other, and distance themselves from it through a false commitment to rights. As women deny their desire for freedom because of a fear that by asserting that desire they risk violent invasion, so human beings, according to Gabel, deny their desire for attachment because they fear that by exposing their deeper and truer need for connection, they will leave themselves vulnerable to the pain of rejection. This fear is rooted in an unconsciously embedded memory from infancy, just as women's fear of their own desire for freedom is rooted in a memory of male violence. At some point in early infancy, according

48 Dworkin, Intercourse at 141-42 (cited in note 42). 
to Gabel, the other (read: the mother) rejected him. That rejection was painful and humiliating. The individual denies his need for connection because he refuses to risk the reenactment of such a painful, humiliating, and embarrassing rejection, just as the woman denies her need for physical individuation because she refuses to risk the reenactment of rape. So instead he creates a false self, defined by liberal "rights." In a word, he collaborates:

Each of us senses that others are determined to keep themselves at what one might call a threatening distance, desiring eye contact and yet forbidding this contact. . . . And because this forbidding distance leads us to mistrust or lose confidence in the desire of the other, we seek to protect ourselves by installing this same forbidding distance in ourselves. We each become "one of the others" to each other, thus helping to create the very disconnection that we most wish others would allow us to overcome. ...

What then is the origin of this mutual mistrust that leads us to adopt a false self that denies its own falsity? For each of us individually, this mistrust originates in our childhoods . . . through direct relations with parents who themselves were conditioned within the "circle of collective denial" through which alienated reciprocities reproduce themselves. As a result of these early experiences of the distancing other, we internalize a memory of loss with which desire itself becomes permanently associated. . . .

Thus the source of alienation is not to be found in the organization of production, or in some particular form of child-rearing, or in a contradiction between self and other inherent in human nature: it derives instead from the incapacity of intersubjective desire to transcend the circular and self-reproducing constraint it has imposed upon itself in response to the fear of loss. ${ }^{49}$

As Gabel by now must surely be aware, his account of the source of "our" alienation from the other is deeply gendered." The story he tells of attachment, separation, longing, rejection, repression, humiliation and then alienation is a story of male development, not female. But structurally, his argument is not at all

49 Gabel, 62 Tex.L.Rev. at 1567-69 (cited in note 11)(citations omitted).

so Gabel briefly alludes to, but then dismisses, an alternative feminist explanation in footnote 12, 62 Tex.L.Rev, at 1568. Conversations with Marcy Wilder and Toni Fitzpatrick (Stanford Law School '88) have helped me see the gender bias in Gabel's work. 
gendered. Dworkin's and Gabel's arguments employ precisely the same logical structure. Dworkin, like Gabel, argues that women engage in massive denial, identification, and collaboration with the powers that cause their alienation. In fact, Gabel's account of male denial of the need for attachment is the structural mirror, although the substantive negative, of Dworkin's account of women's denial of the need for individuation.

Both Gabel's and Dworkin's explanations, I believe, are ultimately unsatisfying, and although they are exploring substantively opposed phenomena, they are unsatisfying for the same reason. Both claims fail to do justice to the complexity of the phenomenology that they are seeking to explain. Others have argued, and I think persuasively, that Gabel's explanation of the disempowered's "collaborative" embrace of rights fails to capture the phenomenological experience of rights as an empowering and even communitarian tool for disempowered peoples. ${ }^{51}$ I will not pursue that argument here. I do want to argue, though, that Dworkin's parallel insistence that women's enjoyment of heterosexual intercourse constitutes a form of collaboration fails to capture the phenomenological experience of intercourse as one of positive intimacy, rather than an experience that is inevitably destructive of "all that is creative within us." Women often, and perhaps increasingly, experience heterosexual intercourse as freely chosen intimacy, not invasive bondage. A radicalism that flatly denies the reality of such a lived experience runs the risk of making itself unintelligible and irrelevant to all people, not to mention the audience that matters most: namely, those women for whom intercourse is not free, not chosen, and anything but intimate, and who have no idea that it either could be or should be both.

This "critique of the intimacy critique" can easily be misconstrued-as can the "critique of the rights critique." I am not denying that heterosexuality is compulsory in this culture or that women as a consequence of that compulsion become alienated from their desire for freedom. It is indeed true, as the lesbian-feminist poet Adrienne Rich argued some time ago, that both heterosexuality and heterosexual intercourse are compulsory. But heterosexuality is compulsory because of the institutions that render it compulsory, not because of the nature of the act. The same is true

s1 See, e.g., Patricia Williams, Alchemical Notes: Reconstructed Ideals from Deconstructed Rights, 22 Harv.Civ.Rts.-Civ.Liberties Law Review 401 (1987) and Richard Delgado, The Ethereal Scholar: Does Critical Legal Studies Have What Minorities Want?, 22 Harv.Civ.Rts.-Civ.Liberties Law Review 301 (1987). 
of motherhood and pregnancy. Because they are compulsory, motherhood and heterosexuality are tremendously constraining, damaging, and oppressive. It is indeed true that the institutions which render them such need to be, ought to be, and will be destroyed. But it does not follow from any of this that either motherhood or intercourse themselves will be, need to be, or ought to be destroyed. As Rich has argued of mothering,

To destroy the institution is not to abolish motherhood. It is to release the creation and sustenance of life into the same realm of decision, struggle, surprise, imagination, and conscious intelligence, as any other difficult, but freely chosen, work..$^{52}$

Similarly, to destroy the "institution" of heterosexual intercourse is not to abolish intercourse. Rather, it is to "release" it into the same realm of decision, struggle, surprise, imagination, and conscious intelligence as any other freely chosen "form"-not of work, as is the case of motherhood-but of intimacy, love, and play.

Now, it is also true-emphatically true-that neither motherhood nor intercourse have been "released" from patriarchy. Until they are, there is no project more vital to our understanding of women's present oppression than the description of the subjective experience of motherhood, and of intercourse, within the patriarchical institutions that render those activities compulsory. This is the importance of Rich's multi-textured work on compulsory motherhood and heterosexuality, and of Dworkin's passionate but disappointingly unidimensional work on intercourse. We need to be aware-to be made aware-of those institutions as institutions that constrain as they define the act. But, as Rich clearly saw with respect to mothering, that is not all we need to understand. Feminists also need to understand what it means to mother and to enjoy intercourse within aspirational conditions of freedom, for it is those conditions which potentially and increasingly, for many of us, define the nature of those events. When we reach this understanding, or at least strive for it, we will have a better understanding of what non-institutional and non-patriarchal intercourse and motherhood might be and might ultimately become.

Of course, to again borrow from Rich, to catch even a glimpse of mothering or intercourse within a non-patriarchal culture requires a "quantum leap" of imagination. It requires, most of all, the ability to imagine ourselves in a society in which women are in

${ }^{62}$ Rich, On Lies, Secrets, and Silence at 272 (cited in note 24). 
full possession of our bodies:

[T]he "quantum leap" [of imagination] implies that even as we try to deal with backlash and emergency, we are imagining the new: a future in which women are powerful, full of our own power, not the old patriarchal power-over but the powerto-create, power-to-think, power-to-articulate and concretize our visions and transform our lives and those of our children. I believe . . . that this power will begin to speak in us more and more as we repossess our own bodies, including the decision to mother or not to mother, and how, and with whom, and when. For the struggle of women to become self-determining is rooted in our bodies, and it is an indication of this that the token women artist or intellectual or professional has so often been constrained to deny her female physicality in order to enter realms designated as male domain. ${ }^{53}$

Yet we make small versions of these "quantum leaps" every day. We continue to mother and to want to mother in spite of the compulsory nature of institutional motherhood. We also make small versions of the same "quantum leap" with respect to intercourse. Women do, increasingly, freely engage in heterosexual intercourse in spite of the compulsory nature of the institution of intercourse. Increasingly, we have a sense of what intercourse feels like when "released" from compulsory heterosexuality. Explanations that rest on denial of the possibility that equality and freedom can define intercourse and motherhood fail to incorporate real glimpses that we increasingly have of a world without the present oppresive institutions. They consequently endanger the seriousness and the truth of the radical feminist insight that many women, indeed most women, define their intimate relationships within the confines of necessity rather than possibility, and within the dictates of compulsion, rather than choice.

The second possible explanation of contradiction between the official story and true subjectivity centers on the Gramscian and Marxist concept of legitimation and apology. Thus, Catharine MacKinnon argues that "intimacy" simply legitimates invasion, and that cultural feminism's celebration of intimacy is, in essence, simply apology for patriarchy:

For women to affirm difference, when difference means dominance, as it does with gender, means to affirm the qualities 
and characteristics of powerlessness. ...

So I am critical of affirming what we have been, which necessarily is what we have been permitted, as if it is women's, ours, possessive. . . .

I do not think that the way women reason morally is morality "in a different voice." I think it is morality in a higher register, in the feminine voice. Women value care because men have valued us according to the care we give them, and we could probably use some. Women think in relational terms because our existence is defined in relation to men. . . . All I am saying is that the damage of sexism is real, and reifying that into differences is an insult to our possibilities. ${ }^{54}$

This explanation has a parallel in critical legal theory. According to critical legalists, the dominant class legitimates the oppressive reality of alienation by relabelling alienation as freedom, just as cultural feminism, according to MacKinnon, relabels invasion as intimacy. Indeed, it is a recurrent claim in critical legal theory that the rhetoric of autonomy and freedom found in nineteenth century contract law, like the rhetoric of good faith and fulfilled expectations in twentieth century contract law, all operate to deny the true human need for connection and collectivity:

The legitimating image of classical contract law in the nineteenth century was the ideal of free competition as the consequence of wholly voluntary interactions among many private persons, all of whom were in their nature free and equal to one another. ... [T] his was denial and apology. It did not take account of the practical limitations on market freedom and equality arising from class position or unequal distribution of wealth. It also ignored other meanings of freedom and equality having to do with the realization of human spirit and potential through work and community. The legitimation of the free market was achieved by seizing upon a narrow economic notion of freedom and equality, and fusing it in the public mind with the genuine meaning. . . .5

The central point to understand from this is that contract law today constitutes an elaborate attempt to conceal what is going on in the world. . . . Contemporary capitalism is a coer-

st Catharine A. MacKinnon, Feminism Unmodified 39 (1987).

ss Peter Gabel and Jay M. Feinman, Contract Law as Ideology, in David Kairys, ed., The Politics of Law 172, 176 (1982)(citation omitted). 
cive system of relationships. ... [0]ur narrow functional roles produce isolation, passivity, unconnectedness and impotence. Contract law, like the other images constituted by capitalism, is a denial of these painful feelings and an apology for the system that produces them..$^{58}$

Again, both MacKinnon's argument and the parallel critical legal claim are unsatisfying, and for the same reason. Both claims fail to do justice to the complexity of the opposing vision they attack. For while it is true that liberalism's commitment to individualism echoes capitalism's legitimating myth of market freedom, this doesn't come anywhere near the whole story. The commitment to individualism that pervades part of liberalism and of liberal culture exists in spite of capitalism's actual disdain for true individualism, not because of capitalism's false claim to freedom. Liberalism has always had a radical commitment to a true individualism which is not in any sense apologist; liberal individualism in at least some of its historical and modern forms undercuts, rather than relegitimates, capitalist super-structure. Similarly, women's ethic of care, and commitment to the value of nurturance and intimacy celebrated by cultural feminism, exists in spite of patriarchy's contempt for and under-valuation of those values, not because of their false claim to honor women's separate sphere. While it is of course true that cultural feminism's celebration of women's ethic of care echoes patriarchy's celebration of separate spheres, the former is hardly an apology for the latter. The differences between cultural feminism and patriarchy are the all-important ones: patriarchy devalues women, and cultural feminism does not. Patriarchy celebrates women's different sphere in order to reinforce women's powerlessness. Cultural feminism does not.

Critical legal theorists have developed a third account of the contradiction between liberal values and subjective desire: the contradiction is based on a real, lived contradiction grounded in material, unreconstructed reality. I believe this explanation is the strongest of the three, though, as far as I know, it has no parallel in feminist theory. Both Roberto Unger and Duncan Kennedy have argued, with considerable force, that the "contradiction" between liberalism's claim that human beings value autonomy and fear the other, and critical theory's opposing claim that they desire connection with the other and dread their alienation from him, reflects a real contradiction in our subjective, material, and natural lives. It 
is not then (solely) the product of either psychoanalytic denial or Gramscian legitimation. The contradiction is an experiential contradiction, not a logical contradiction. The difference is important.

According to Kennedy, we value both autonomy and connection, and fear both annihilation by the other and alienation from him, and all for good reason. The other is both necessary to our continued existence and a threat to that continued existence. While it is true that the dominant liberal story of autonomy and annihilation serves to perpetuate the status quo, it does not follow from that fact that the subjective desires for freedom and security which those liberal values reify are entirely false. Rather, Kennedy argues, collectivity is both essential to our identity and an obstacle to it. We have contradictory desires and values because our essential human condition-physical separation from the collectivity which is necessary to our identity-is itself contradictory. It is that essential human condition which carries the seeds of our twin fears of alienation and annihilation, as well as our twin desires for autonomy and attachment:

Here is an initial statement of the fundamental contradiction: ... Others (family, friends, bureaucrats, cultural figures, the state) are necessary if we are to become persons at all-they provide us the stuff of our selves and protect us in crucial ways against destruction. Even when we seem to ourselves to be most alone, others are with us, incorporated in us through processes of language, cognition and feeling that are, simply as a matter of biology, collective aspects of our individuality. Moreover, we are not always alone. We sometimes experience fusion with others, in groups of two or even two million, and it is good rather than a bad experience.

But at the same time that it forms and protects us, the universe of others (family, friendship, bureaucracy, culture, the state) threatens us with annihilation and urges upon us forms of fusion that are quite plainly bad rather than good. ... Numberless conformities, large and small abandonments of self to others, are the price of what freedom we experience in society. And the price is a high one. ${ }^{.7}$

Roberto Unger provides a more general account of this fundamental contradiction:

s7 Duncan Kennedy, The Structure of Blackstone's Commentaries, 28 Buffalo L.Rev. 209, 211-12 (1979). 
The problem to be solved is that of reconciling two primitive human demands. One is the need to preserve independence from the outside world. The other demand is the equally basic need of the self to live in a world transparent to its mind and responsive to its concerns, a world with which it can therefore be at one. The situation in which man is at one with nature though separate from it, in which he has overcome his moral and cognitive estrangement without losing his independence, is natural harmony. . . .

If we take nature for the nonhuman world, natural harmony will be the experience of belonging to that world while also standing apart from it. This is what Marx seems to have in mind when he speaks of the condition in which nature is humanized and man naturalized. ${ }^{88}$

This third explanation of the contradiction between liberal ideology and critical descriptive claims might, of course, just be wrong. The value the individual places on autonomy and the fear he claims to have of annihilation may reflect only the effectiveness of legitimation and apology, or the thoroughness of psychoanalytic denial. But if Kennedy is wrong, he is wrong in a way that is shared by the practicing legal culture itself. For as any good law student knows, on an empirical level Kennedy is clearly right: our legal doctrine, or at least our legal ideology, does indeed reflect the contradictory fundamental urges that Kennedy has identified. Any sufficiently rich statement of any area of legal doctrine quite explicitly reflects both the "official" story of our values as told by liberal legalism and the "unofficial" story of a sharply contrasting subjectivity as told by critical theory. If we generalize the point, we might say that the "Rule of Law" itself reflects the fundamental contradiction. The Rule of Law itself values and protects our autonomy and minimizes the dangers that are consequent to our vulnerability. That's its official role. But it also has an unofficial, underground, subterranean potentiality, only occasionally recognized, but nevertheless always there. The Rule of Law is a product of our dread of alienation from the other and our longing for connection with him, no less than it is a product of love of autonomy and fear of annihilation by him. As a consequence, it can be used and occasionally is used to ameliorate the sorrow we feel as a consequence of our alienation, as well as to protect the autonomy we value against the very real threat of annihilation.

${ }^{38}$ Unger, Knowledge and Politics at 205 (cited in note 3). 
The strength of Duncan Kennedy's work is that he has not just asserted the existence of this fundamental contradiction, but has shown its permeation through a remarkably wide range of legal materials. The structurally parallel claim in feminist theory that I think radical feminists should explore, is that women "officially" value intimacy (and fear separation) in spite of subjective desires to the contrary not (solely) because of the legitimating power of patriarchal ideology, nor (solely) because of the power of denial, but rather, because women's existential and material circumstance is itself one of contradiction. The potentiality for physical connection with others that uniquely characterizes women's lives has within it the seeds of both intimacy and invasion, and therefore women rightly value the former while we dread and fear the latter, just as the necessity of physical separation, for men, carries within it the seeds of both intimacy and alienation, and men rightly value the former and dread the latter. If this is right, then all four accounts of human experience-liberal legalism, critical legalism, cultural feminism and radical feminism-are saying something true about human experience. Liberal legalism and critical legalism both describe something true about male experience, and cultural feminism and radical feminism both describe something true about female experience. If Kennedy is right, then men simply live with an experiential contradiction. In a parallel fashion, cultural feminism and radical feminism may both be true although contradictory. The contradiction between them may be experiential rather than logical. Women may both value intimacy and dread the intrusion and invasion which intimacy implies; and women may both fear separation and long for the individualization which separation would bring.

Although Andrienne Rich has argued something like this with respect to motherhood, no radical feminist has, to my knowledge, advanced this claim with respect to intercourse. Nor has anyone advanced the claim with respect to the fear of invasion and the value of intimacy generally. Andrea Dworkin alludes to the possibility that women may desire and enjoy physical intimacy with men for admirable reasons only once in her book-long treatise on intercourse, and even that reference is lodged almost invisibly in a paragraph whose overriding argument is very much to the contrary. Nevertheless, even that one reference is rich with the suggestion of a fundamental contradiction. Any full analysis of women's experience of intercourse, I am sure, must develop the essential contradiction in our experience to which Dworkin alludes (but does not develop) in this paragraph: 
Women have wanted intercourse to work and have submitted . . . even though or even when it does not. The reasons have often been foul, filled with the spiteful but carefully hidden malice of the powerless. Women have needed what can be gotten through intercourse: the economic and psychological survival; access to male power through access to the male who has it; having some hold-psychological, sexual, or economic-on the ones who act, who decide, who matter. There has been a deep, consistent, yet of course muted objection to what Anais Nin has called "[t]he hunter, the rapist, the one for whom sexuality is a thrust, nothing more." Women have also wanted intercourse to work in this sense: women have wanted intercourse to be, for women, an experience of equality and passion, sensuality and intimacy. Women have a vision of love that includes men as human too; and women want the human in men, including in the act of intercourse. Even without the dignity of equal power, women have believed in the redeeming potential of love. There has been-despite the cruelty of exploitation and forced sex-a consistent vision for women of a sexuality based on a harmony that is both sensual and possible. . . . These visions of a humane sensuality based in equality are in the aspirations of women; and even the nightmare of sexual inferiority does not seem to kill them.

They also do not amount to much in real life with real men. There is, instead, the cold fucking, duty-bound or promiscuous; the romantic obsession in which eventual abandonment turns the vagina into the wound Freud claimed it was; intimacy with men who dread women, coital dread-as Kafka wrote in his diary, "coitus as punishment for the happiness of being together."

Minimally, I want to suggest that feminists should think about the possibility that the notion of a "fundamental" experienced contradiction, grounded in the material and existential state of connection with the other, might help us explain women's subjective lives, as well as close the broadening gap between cultural and radical feminist theory. The presence of such a contradiction, for example, explains why some women see the possibility of intimacy in pornographic depictions of female sexual submission while others see the threat of invasion (and it would explain why many

${ }^{69}$ Dworkin, Intercourse at $128-29$ (cited in note 42)(emphasis added). 
women see both). The presence of a contradiction underlying women's subjective lives also clarifies the existential basis of many of the apparent tensions in feminist legal reforms. It explains why women insist upon and embrace an ethic of care and the right to have children without economic hardship, while at the same time fighting for rights of individuation, physical privacy, and freedom. Finally, it explains the complex relationship between the emerging feminist legal theory and dominant legal theory: it explains, for example, why legal feminists are both attracted to liberal rights of individuation, physical privacy, and individual security, and at the same time are threatened by them. The contradiction explains why feminists understand, and even sympathize with, critical legal theory's rights critique, but will never endorse it.

That women live with a fundamental contradiction between invasion and intimacy is much harder to test than the parallel claim that men live in a fundamental contradiction between autonomy and alienation for this simple reason: the fundamental contradiction that characterizes men's lives is manifested absolutely all over the place in public life. As Kennedy correctly claims, once we are sensitized to it, we see the "fundamental contradiction" in art, literature, music, and, perhaps most emphatically, in virtually every field of law. The fundamental contradiction that characterizes women's lives (if it does), by contrast, has no outlet. Women are silent, particularly with respect to the injuries we suffer. This is, of course, changing: Women speak, write books, compose music, produce art, drama and dance, and increasingly even legislate, advocate and adjudicate law. But nevertheless, women express their subjectivity with nowhere near the voice of authority with which men express theirs. Women's subjectivity, unlike men's subjectivity, is not expressed in the objective world. Women's silence, more than any other single factor, inhibits the study of women's subjective lives.

We can, though, test the sense of this contradiction against the evidence of our own experienced lives, if not the evidence of art, literature and legal doctrine. When I read Carol Gilligan's book for the first time several years ago, I had an unequivocal shock of recognition. What she is saying, I thought then and still think, is important, transformative, empowering, exciting, enlivening, and, most fundamentally, it is simply true. It is true of me, and was true of my mother, and is true of my sisters. She has described the way I think, what I value, what I fear, how I have grown, and how I hope to grow. And she has described the moral lives of the women I know as well. Her book captures what I know 
and have always known but have never been able to claim as my own moral vision, and what parts of that vision I share with women generally. When I read Andrea Dworkin's book, I had the same unequivocal shock of recognition. What Dworkin is saying about intercourse is important, transformative, empowering, exciting, liberating, enlivening, and most fundamentally, it is simply true. It is true of me, was true of my mother, and is true of my sisters. She is describing how I have been debased, victimized, intruded, invaded, harmed, damaged, injured, and violated by intercourse. Yet it also seems undeniably true to me that these two feminist visions of my subjective life rest on flatly contradictory premises.

This realization-if it is shared-presents us with a choice. We can assume that the contradictions in feminist descriptions of our lives are conceptual, in which case we must look for flawed arguments-we cannot and ought not believe contradictory things. Alternatively, we can start to think about the possibility that the contradiction in women lives is experientially felt and materially based. Kennedy's account of the dilemma that contradiction poses for the legal theorist, I believe, is equally true of the dilemma that the very different contradiction in women's lives now poses for feminism:

The acknowledgment of contradiction does not abate the moral and practical conflict, but it does permit us to make some progress in characterizing it. At an elementary level, it makes it clear that it is futile to imagine that moral and practical conflict will yield to analysis in terms of higher level concepts. The meaning of contradiction at the level of abstraction is that there is no metasystem that would, if only we could find it, key us into one mode or the other as circumstances "required." Second, the acknowledgement of contradiction means that we cannot "balance" individualist and altruist values or rules against equitable standards. . . . The imagery of balancing presupposes exactly the kind of more abstract unit of measurement that the sense of contradiction excludes. The only kind of imagery that conveys the process by which we act and act and act in one direction, but then reach the sticking point, is that of existentialist philosophy. We make commitments, and pursue them. The moment of abandonment is no more rational than that of beginning, and equally a moment 
of terror. ${ }^{60}$

Of course, there is a major difference between the presence of contradiction in legal theory and the presence of contradiction in feminist theory. Even if it is true that women, like men, live within the parameters of a contradiction, women live within the parameters of this fundamental contradiction within the oppressive conditions of patriarchy. Men don't (although men do live within the parameters of the oppressive conditions of capitalism). Therefore, feminists need to develop not just an examination of the experience of the contradiction between invasion and intimacy to which our potential for connection gives rise, but also a description of how patriarchy effects, twists, perverts, and surely to some extent causes that contradiction. We also need, however, to imagine how the contradiction would be felt outside of patriarchy, and we need to reflect on our own experiences of non-patriarchal mothering, intercourse, and intimacy to generate such imaginings. For while women's bodies may continue to be "materially connected" to others as long as they are women's bodies, they need not forever be possessed by others. Our connection to the other is a function of our material condition; our possession by the other, however, is a function of patriarchy. We need to imagine both having power over our bodies and power over our contradictory material state. We need to imagine how this fundamental contradiction would feel outside of the context of the dangers and fears that patriarchy requires. Adrienne Rich asks, of non-constrained, non-compulsory, truly chosen motherhood in a world free of patriarchy:

What would it mean to mother in a society where women were deeply valued and respected, in a culture which was womanaffirming? What would it mean to bear and raise children in the fullness of our power to care for them, provide for them, in dignity and pride? . . . What would it mean to mother in a society which was making full use of the spiritual, intellectual, emotional, physical gifts of women, in all our difference and diversity? What would it mean to mother in a society which laid no stigma upon lesbians, so that women grew up with real emotional and erotic options in the choice of life companions and lovers? What would it mean to live and die in a culture which affirmed both life and death, in which both the living world and the bodies of women were released at last from centuries of violation and control? This is the quantum leap of

${ }^{60}$ Kennedy, 89 Harv.L.Rev. at 1775 (cited in note 12). 
the radical feminist vision. ${ }^{61}$

We need to ask these questions of intercourse as well. What would intercourse feel like, or be, in a world in which it was freely chosen? What would it mean to have intercourse in a world in which women's pleasures were honored, and women's injuries were cared for, and women's labor was compensated? And finally we need to ask these questions of intimacy generally. How would the "contradiction" between invasion and intimacy feel in a world free of the fear of male sexual aggression? Would intimacy be entirely non-threatening where there was no reason to fear rape? Would individuation be as enticing where intercourse and motherhood were not mandatory? Would separation be as harmful where familial association was not the assumed form of women's lives? How would the contradiction between intimacy and intrusion feel, if we had no reason to fear the more life threatening forms of invasion? We need to ask these questions, but we also need to answer them. The answers, I suspect, must come at least in part from the nonpatriarchal relationships in our own lives. We should not be surprised when, as we look at those lives, we see and feel contradictions, not just within the structures of patriarchy, but behind them, through them, and beyond them as well.

\section{Feminist JuRISPRUDENCE}

By the claim that modern jurisprudence is "masculine," I mean two things. First, I mean that the values, the dangers, and what I have called the "fundamental contradiction" that characterize women's lives are not reflected at any level whatsoever in contracts, torts, constitutional law, or any other field of legal doctrine. The values that flow from women's material potential for physical connection are not recognized as values by the Rule of Law, and the dangers attendant to that state are not recognized as dangers by the Rule of Law.

First, the Rule of Law does not value intimacy-its official value is autonomy. The material consequence of this theoretical undervaluation of women's values in the material world is that women are economically impoverished. The value women place on intimacy reflects our existential and material circumstance; women will act on that value whether it is compensated or not. But it is not. Nurturant, intimate labor is neither valued by liberal legalism nor compensated by the market economy. It is not compensated in 
the home and it is not compensated in the workplace-wherever intimacy is, there is no compensation. Similarly, separation of the individual from his or her family, community, or children is not understood to be a harm, and we are not protected against it. The Rule of Law generally and legal doctrine in its particularity are coherent reactions to the existential dilemma that follows from the liberal's description of the male experience of material separation from the other: the Rule of Law acknowledges the danger of annihilation and the Rule of Law protects the value of autonomy. Just as assuredly, the Rule of Law is not a coherent reaction to the existential dilemma that follows from the material state of being connected to others, and the values and dangers attendant to that condition. It neither recognizes nor values intimacy, and neither recognizes nor protects against separation.

Nor does the Rule of Law recognize, in any way whatsoever, muted or unmuted, occasionally or persistently, overtly or covertly, the contradiction which characterizes women's, but not men's, lives: while we value the intimacy we find so natural, we are endangered by the invasion and dread the intrusion in our lives which intimacy entails, and we long for individuation and independence. Neither sexual nor fetal invasion of the self by the other is recognized as a harm worth bothering with. Sexual invasion through rape is understood to be a harm, and is criminalized as such, only when it involves some other harm: today, when it is accompanied by violence that appears in a form men understand (meaning a plausible threat of annihilation); in earlier times, when it was understood as theft of another man's property. But marital rape, date rape, acquaintance rape, simple rape, unaggravated rape, or as Susan Estrich wants to say "real rape"62 are either not criminalized, or if they are, they are not punished-to do so would force a recognition of the concrete, experiential harm to identity formation that sexual invasion accomplishes.

Similarly, fetal invasion is not understood to be harmful, and therefore the claim that I ought to be able to protect myself against it is heard as nonsensical. The argument that the right to abortion mirrors the right of self defense falls on deaf ears for a reason: the analogy is indeed flawed. The right of self defense is the right to protect the body's security against annihilation liberally understood, not invasion. But the danger an unwanted fetus poses is not to the body's security at all, but rather to the body's

62 Susan Estrich, Real Rape (1987). 
integrity. Similarly, the woman's fear is not that the she will die, but that she will cease to be or never become a self. The danger of unwanted pregnancy is the danger of invasion by the other, not of annihilation by the other. In sum, the Rule of Law does not recognize the danger of invasion, nor does it recognize the individual's need for, much less entitlement to, individuation and independence from the intrusion which heterosexual penetration and fetal invasion entails. The material consequence of this lack of recognition in the real world is that women are objectified-regarded as creatures who can't be harmed.

The second thing I mean to imply by the phrase "masculine jurisprudence" is that both liberal and critical legal theory, which is about the relation between law and life, is about men and not women. The reason for this lack of parallelism, of course, is hardly benign neglect. Rather, the distinctive values women hold, the distinctive dangers from which we suffer, and the distinctive contradictions that characterize our inner lives are not reflected in legal theory because legal theory (whatever else it's about) is about actual, real life, enacted, legislated, adjudicated law, and women have, from law's inception, lacked the power to make law protect, value, or seriously regard our experience. Jurisprudence is "masculine" because jurisprudence is about the relationship between human beings and the laws we actually have, and the laws we actually have are "masculine" both in terms of their intended beneficiary and in authorship. Women are absent from jurisprudence because women as human beings are absent from the law's protection: jurisprudence does not recognize us because law does not protect us. The implication for this should be obvious. We will not have a genuinely ungendered jurisprudence (a jurisprudence "unmodified" so to speak) until we have legal doctrine that takes women's lives as seriously as it takes men's. We don't have such legal doctrine. The virtual abolition of patriarchy is the necessary political condition for the creation of non-masculine feminist jurisprudence.

It does not follow, however, that there is no such thing as feminist legal theory. Rather, I believe what is now inaccurately called "feminist jurisprudence" consists of two discrete projects. The first project is the unmasking and critiquing of the patriarchy behind purportedly ungendered law and theory, or, put differently, the uncovering of what we might call "patriarchal jurisprudence" from under the protective covering of "jurisprudence." The primary purpose of the critique of patriarchal jurisprudence is to show that jurisprudence and legal doctrine protect and define men, not 
women. Its second purpose is to show how women-that is, people who value intimacy, fear separation, dread invasion, and crave individuation-have fared under a legal system which fails to value intimacy, fails to protect against separation, refuses to define invasion as a harm, and refuses to acknowledge the aspirations of women for individuation and physical privacy.

The second project in which feminist legal theorists engage might be called "reconstructive jurisprudence." The last twenty years have seen a substantial amount of feminist law reform, primarily in the areas of rape, sexual harassment, reproductive freedom, and pregnancy rights in the workplace. For strategic reasons, these reforms have often been won by characterizing women's injuries as analogous to, if not identical with, injuries men suffer (sexual harassment as a form of "discrimination;" rape as a crime of "violence"), or by characterizing women's longing as analogous to, if not identical with, men's official values (reproductive freedom-which ought to be grounded in a right to individuation-conceived instead as a "right to privacy," which is derivative of the autonomy right). This misconceptualization may have once been a necessary price, but it is a high price, and, as these victories accumulate, an increasingly unnecessary one. Reconstructive feminist jurisprudence should set itself the task of rearticulating these new rights in such a way as to reveal, rather than conceal their origin in women's distinctive existential and material state of being. The remainder of this article offers a schematization and criticism of the feminist jurisprudence we have generated to date under the umbrella concept described above, in spite of patriarchy and in spite of the masculinity of legal theory. I then suggest further lines of inquiry.

\section{A. The Critique of Patriarchal Jurisprudence}

Structurally, the feminist attempt to describe and critique patriarchal jurisprudence by necessity tracks the methodological divisions in masculine jurisprudence, so I need to make one further diversion. Masculine jurisprudence is divided internally by a methodological issue which is as definitive and foundational as the substantive issues that divide liberal from critical legalism. Some legal theorists practice what might be called a "narrative" and "phenomenological" jurisprudential method, (hereinafter, simply narrative) and some practice what might be called an "interpretivist" method. Narrative and interpretive methodology have adherents in both liberal and critical legal literature. Thus, if we look at both substance and method, (instead of just substance) there are not 
two, but four major jurisprudential traditions in legal scholarship. Liberal legalism can be either interpretive or narrative, as can critical legal theory. Put differently, a narrative methodology can be either critical or liberal, as can interpretivism.

"Narrative legal theory," whether it be liberal or critical, moves methodologically from a description of justice, the state of nature, or of the "human being" which aims for some degree of generality if not universality, and then tells either a narrative story about how human beings thus described come to agree on the Rule of Law, or, alternatively, a phenomenological description of how it feels to be a person within a legal regime. To the narrative and phenomenological legal theorists, (whether critical or liberal) the person, the natural state, and the demands of justice are first, both historically and phenomenologically. Human beings create the Rule of Law from the state of nature to comply with the demands of justice and the narrative theorist tells how and why."Interpretive" jurisprudence, whether liberal or critical, moves methodologically in the opposite direction. Interpretive theorists begin with an interpretation of law, or of a body of legal doctrine, or of the idea of law itself, and derive from that interpretation an account of justice. The methodological assumption of interpretive jurisprudence is that the legal text not only reflects, but to some degree even defines, what justice requires and hence what a person is. It is the purpose of interpretive jurisprudence to provide the best interpretation of the "justice" that the legal text has defined. Thus, the interpretivist tells the story of justice from the point of view of the rule of law, rather than the story of the emergence of "law" from the point of view of human beings under the constraints of justice. While to the narrative theorist, "we" create legal texts, to the interpretivists, the texts "create" as they define our moral commitments and hence our view of ourselves, and it is the theorist's special role to show exactly who it is that the texts have created.

Putting together substance and method, we can generate a four-boxed matrix: narrative liberal legalism, interpretive liberal legalism, narrative critical theory and interpretive critical theory. The matrix, with representative participants, looks like this: 
NARRATIVE

\begin{tabular}{|l|l|l|}
\hline LIBERAL & $\begin{array}{l}\text { Hobbes, } \\
\text { Ackerman, } \\
\text { Rawls }\end{array}$ & $\begin{array}{l}\text { Blackstone } \\
\text { R. Dworkin }\end{array}$ \\
\hline CRITICAL & $\begin{array}{l}\text { "Phenomenology } \\
\text { Project" (rights) } \\
\text { Unger, Gabel }\end{array}$ & $\begin{array}{l}\text { D. Kennedy } \\
\text { "Deconstruction } \\
\text { Project" }\end{array}$ \\
\hline
\end{tabular}

1. The Narrative and Phenomenological Critique. By "the critique of patriarchal jurisprudence" I mean four distinct projects, which parallel the matrix given above. First, narrative critical jurisprudence aims to provide, in a Hobbesian (or Ungerian) manner, the material, internal, phenomenological, subjective story of women's experience of the emergence and present reality of the Rule of Law. That story goes something like this. Prior to the advent of the "Rule of Law," we might hypothesize, women bore, breast fed, nurtured and protected children. Women did the nurturant work. As described above, women lived in a "natural web of hierarchy:" they were profoundly unequal to the infants they raised. While men responded to their condition of natural equality with mutual aggression, women responded to their condition of natural inequality with nurturance and an ethic of care. Women were at the same time profoundly unequal to men. Prior to the Rule of Law, women, and only women, were vulnerable to sexual invasion. As Catharine MacKinnon suggests, on the only "first day that matters," and this day occurred long before the signing of the social contract, men established sexual power over women. ${ }^{63}$ Thus, inequality vis-a-vis both children and men, an ethic of care for the weak, and sexual vulnerability to the male, was women's natural state, while equality, mutual fear and suspicion was men's.

Then, on day two, came the Rule of Law. According to the Hobbesian story, the Rule of Law significantly improved the quality of men's lives: men's lives became longer, less nasty, less brutish (even if somewhat more alienated), and more productive. But not so for women: the same Rule of Law left women's natural lives intact, worsened her material condition, and reified her sexual vulnerability into a male right of access. The Rule of Law changed the conditions that uniquely pertained to women in the state of nature, but the change was for the worse: after the Rule of Law,

6s MacKinnon, Feminism Unmodified at 40 (cited in note 54). 
women are still uniquely capable of intimacy, but newly unrecognized for their nurturant activity in a world that values autonomy and compensates individuated labor. Similarly, women remain uniquely vulnerable to invasion, but newly unprotected against that injury in a world that protects against other injuries. The narrative and phenomenological task for the critique of patriarchal jurisprudence is to tell the story and phenomenology of the human community's commitment to the Rule of Law from women's point of view. We need to show what the exclusion of women from law's protection has meant to both women and law, and we need to show what it means for the Rule of Law to exclude women and women's values.

The way to do this-the only way to do this-is to tell true stories of women's lives. The Hobbesian "story" of deliverance from the state of nature to the Rule of Law, as both liberal and radical legal scholars are fond of pointing out, does not purport to be history. But that doesn't make it fantasy. The Hobbesian story of the state of nature (and the critical story of alienation as well) is a synthesis of umpteen thousands of personal, subjective, everyday, male experiences. Images are generated from that synthesis, and those images, sometimes articulate, sometimes not, of what it means to be a human being then become the starting point of legal theory. Thus, for example, the Hobbesian, liberal picture of the "human being" as someone who treasures autonomy and fears annihilation from the other comes from men's primary experiences, presumably, of school yard fights, armed combat, sports, games, work, big brothers, and fathers. Similarly, the critical picture of the human being as someone who longs for attachment and dreads alienation comes from the male child's memory of his mother, from rejection experiences painfully culled from his adolescence, and from the adult male's continuing inability to introspect, converse, or commune with the natural world, including the natural world of others. When Peter Gabel says "Let me start by making a descriptive assertion [about human beings] ... which seems to me ... [to be] self-evidently true" statement which is self-evidently untrue of women, he is not simply "mistaken," he is mistaken in a particular (male) way and for a particular (male) reason. When Hobbes, Ackerman, Dworkin, Rawls and the rest of the liberal tradition describe the natural human predicament as one of natural equality and mutual antago-

b4 Gabel, 62 Tex.L.Rev. at 1566 (cited in note 11). 
nism, and describe human beings as inevitably separate and mutually self-interested, thus definitionally excluding pregnant women and breast-feeding mothers from the species, they also are mistaken in a particular way and for a particular reason. Gabel has confused his male experience of separation and alienation with "human" experience, and liberals have confused their male experiences of natural equality, mutual suspicion, fear of annihilation, and pervasive, through-and-through selfishness with "human" experience, and they have done so because women have not made clear that our day-to-day, lived experience-of intimacy, bonding, separation, sexual invasion, nurturance and intrusion-is incommensurable with men's. We need to flood the market with our own stories until we get one simple point across: men's narrative story and phenomenological description of law is not women's story and phenomenology of law. We need to dislodge legal theorists' confidence that they speak for women, and we need to fill the gap that will develop when we succeed in doing so.

Put phenomenologically, instead of narratively, feminist legal theorists need to show through stories the value of intimacy-not just to women, but to the community-and the damage done-again, not just to women, but to the community-by the law's refusal to reflect that value. Indeed, I can't imagine any project more crucial, right now, to the survival of this species than the clear articulation of the importance of love to a well-led public life. We not only need to show that these values are missing from public life and not rewarded in private life, but we also need to show how our community would improve if they were valued. We need to show, (as Suzanna Sherry, ${ }^{85}$ Lynne Henderson, ${ }^{66}$ Martha Minow $^{67}$ and others have begun to do), that a community and a judiciary that relies on nurturant, caring, loving, empathic values rather than exclusively on the rule of reason will not melt into a murky quagmire, or sharpen into the dreaded spector of totalitarianism.

On a more local level, we need to show that a law school which employs, protects, and even compensates for these competencies will be a better law school. We need to show, (as Martha Fineman has done in the area of custody decisions ${ }^{68}$ ), that a legal and eco-

os Sherry, 72 Va.L.Rev. at 584 (cited in note 14); Suzanna Sherry, The Gender of Judges, 4 Law \& Inequality 159 (1986).

so Henderson, Legality and Empathy, __ Mich.L.Rev. _ (forthcoming 1987).

67 Martha Minow, Foreword: Justice Engendered, 101 Harv.L.Rev. 10 (1987).

${ }^{8}$ Martha L. Fineman and Anne Opie, The Uses of Social Science Data in Legal Poli- 
nomic system which values, protects and rewards nurturant labor in private life will make for a better community. We need to show that community, nurturance, responsibility, and the ethic of care are values at least as worthy of protection as autonomy, self-reliance, and individualism. We must do that, in part, by showing how those values have affected and enriched our own lives. Similarly, we need to show-and again, I think we need to do it with stories-how the refusal of the legal system to protect those values has weakened this community, as it has impoverished our lives.

From a radical point of view, we also need to explain, through stories, how physical invasion and intrusion harm women, and how they harm women distinctively. We need to explain, as Susan Estrich, Lynn Henderson and Diana Russell have begun to do, the danger and the harm of rape that is not seen as rape: invasive marital intercourse and invasive intercourse with "dates." to explain how it feels to live entirely outside the protection of rape law: how it feels to be a wife in a state which defines rape as the "nonconsensual sexual intercourse by a man with a woman not his wife;" how it feels to be the person that another person has a legal right to invade without your consent. We need to provide stories rich enough to show that this harm is not the harm of annihilation protected by the Rule of Law, although it may accompany it. We need to show that the harm of invasive intercourse is real even when it does not look like the kind of violence protected by the Rule of Law. We need to show that invasive intercourse is a danger even when it cannot be analogized in any way whatsoever to male experience.

Similarly, we need to explain, as the National Abortion Rights Action League has begun to do, the harms and dangers of invasive pregnancy. We need to explain that this harm has nothing to do with invading the privacy of the doctor-patient relationship, or the privacy of the family, or the privacy of the marriage; but that rather, it has to do with invading the physical boundaries of the body and the psychic boundaries of a life. Finally, we need to provide phenomenological accounts of those ameliorative institutions, ideologies and psychic constructs that purport to make the invasiveness and intrusiveness of our lives tolerable. Romance, for ex-

cymaking: Custody Determination at Divorce, 1987 Wisc.L.Rev. 107; Martha L. Fineman, A Reply to David Chambers, 1987 Wisc.L.Rev. 165; Martha L. Fineman, Dominant Discourse, Professional Language and Legal Change, 101 Harv.L.Rev. - (forthcoming 1988).

${ }^{8}$ Estrich, Real Rape (cited in note 62); Henderson, Book Review, _- Berkeley Women's L.J. _ (forthcoming 1988); Diana E.H. Russell, Rape in Marriage (1982). 
ample, is one such cluster: just as liberal rights mediate the gulf between the liberal value of autonomy and the subjective craving for connection in liberal legalism, so romance mediates the gulf between the feminine value of intimacy and the subjective craving for individuation. The mystique of femininity is surely another, and the pornographic imagination is a third. With the exception of MacKinnon and Dworkin's work on pornography, we haven't done much of this sort of jurisprudence, and we need to do a lot more.

2. The Interpretive Critique. The purpose of the interpretive critique of patriarchal jurisprudence complements that of the narrative critique. As the narrative critique explores the Rule of Law from women's point of view, the interpretive critique aims to explore women from the point of view of the Rule of Law. The interpretive critique shows how patriarchal doctrine constructs, defines, and delimits women, just as interpretive masculine jurisprudence, both liberal and critical, aims to provide accounts of how doctrine constructs, defines, and delimits the human being. For although women-people who value intimacy and are harmed by invasion-have not been accorded the protection of the Rule of Law, we have hardly been ignored. Women are not constructed as human within this system, but we are nevertheless constructed as something else: as valueless, as objects, as children, or as invisible. The interpretive critique should aim to articulate what that something else might be. The interpretive critique is a lot like shining a light on darkness, or proving a negative-it involves looking at what lies between the images of legalism, instead of looking directly at legalism. The interpretive critique must deconstruct the images that authoritatively diminish women, sometimes down to nothing.

On the cultural side of the substantive divide, this means showing how legalism devalues women, by not valuing what women value. To name just a few examples, Martha Fineman has tried to show who and what a "mother" is understood to be in a legal system where nurturant labor is neither recognized nor valued in custody disputes. ${ }^{70}$ Other interpretive cultural feminists have tried to show what it means, objectively, not to be paid for housework, for child-raising, and for relational work in the workplace. On the radical side, this means showing what it means to be objectified. Again, to take just a few examples, Andrea Dworkin has begun to

${ }^{70}$ Martha L. Fineman, Dominant Discourse: The Professional Appropriation of Child Custody Decision-Making, Institute For Legal Studies, Working Papers Series 2 (April 1987). 
show who the "woman" is defined to be by the pornographer, and Catharine MacKinnon has begun to show how the First Amendment has defined the pornographer's definition of the woman. ${ }^{71}$ Susan Estrich, Diana Russell, and others have begun to show what a "wife" is in a legal system which defines rape as the nonconsensual intercourse by a man with a woman not his wife. ${ }^{72}$ We need, I think, to do more of this: most notably, we need to understand how laws criminalizing abortion construct "motherhood" and how Roe $v$. Wade ${ }^{73}$ - which constructs the right to abortion as the product of a need to balance medicinal privacy rights of doctors and patients against the right to life of a fetus-constructs the female. Henderson has done some of this work. ${ }^{74}$ The matrix I foresee, with a sample of representative participants, looks like this:

CRITIQUE OF PATRIARCHAL JURISPRUDENCE

\begin{tabular}{|c|c|c|}
\hline & CULTURAL FEMINISM & RADICAL FEMINISM \\
\hline \multirow[t]{2}{*}{$\begin{array}{l}\text { Interpretive } \\
\text { Jurisprudence }\end{array}$} & $\begin{array}{l}\text { Sherry and Henderson } \\
\text { (on judging) } \\
\text { Fineman (motherhood) } \\
\text { Dalton (midwives) }\end{array}$ & $\begin{array}{l}\text { Mackinnon (first amend) } \\
\text { A. Dworkin (pornography) } \\
\text { Estrich (rape) }\end{array}$ \\
\hline & \multicolumn{2}{|c|}{ DECONSTRUCTION PROJECTS } \\
\hline \multirow[t]{2}{*}{$\begin{array}{l}\text { Narrative } \\
\text { Jurisprudence }\end{array}$} & $\begin{array}{l}\text { Littleton } \\
\text { Fineman }\end{array}$ & $\begin{array}{l}\text { NARAL (Abortion) } \\
\text { MacKinnon (sex harass) } \\
\text { Estrich (rape) }\end{array}$ \\
\hline & \multicolumn{2}{|c|}{$\begin{array}{l}\text { PHENOMENOLOGICAL PROJECTS } \\
\text { (of romance, porn, etc.) }\end{array}$} \\
\hline
\end{tabular}

B. Reconstructive Jurisprudence

The goal of reconstructive feminist jurisprudence is to render feminist reform rational. We must change the fact that, from a mainstream point of view, arguments for feminist legal reform efforts are (or appear to be) invariably irrational. The moral questions feminist reforms pose are always incommensurable with dominant moral and legal categories. Let me put it this way: given

22 MacKinnon, Feminism Unmodified at 206-13 (cited in note 54).

72 Estrich, Real Rape (cited in note 62); Russell, Rape in Marriage (cited in note 69).

73410 U.S. 113 (1973).

74 Henderson, _ Mich.L.Rev. _ (cited in note 66). 
present moral categories, women's issues are crazy issues. Arguments for reproductive freedom, for example, are a little insane: pro-choice advocates can't explain the difference between reproductive freedom and infanticide; or how this right can possibly be grounded in the Constitution; or how it is that women can claim to be "nurturant" and at the same time show blatant disregard for the rights and feelings of fetuses. In fact, my sense, drawn from anecdotal evidence only, is that the abortion issue is increasingly used in ethics as well as constitutional law classrooms to exemplify the "irrationality" of individual moral commitment. Rape reform efforts that aim to expand the scope of the defined harm are also perceived, I believe, as insane. Why would anyone possibly object to non-violent sex? Isn't sex always pleasurable? Feminist pornography initiatives are viewed as irrational, and the slirrogate motherhood issue is no better. There's an air of irrationality around each of these issues.

That air of irrationality is partly real and partly feigned. The reason for the air of irrationality around particular, substantive feminist legal reform efforts, I believe, is that feminist legal reforms are by necessity advocated in a form that masks rather than reflects women's true subjective nature. This is hardly surprising: language, of course, constrains our descriptive options. But whether or not surprising, the damage is alarming, and we need to understand its root. Arguments for reproductive freedom, for example, are irrational because the categories in which such arguments must be cast are reflective of men's, not women's, nature. This culture thinks about harm, and violence, and therefore self defense, in a particular way, namely a Hobbesian way, and a Hobbesian conception of physical harm cannot possibly capture the gender-specific subjective harm that constitutes the experience of unwanted pregnancy. From a subjective, female point of view, an abortion is an act of self defense, (not the exercise of a "right of privacy") but from the point of view of masculine subjectivity, an abortion can't possibly be an act of self defense: the fetus is not one of Hobbes' "relatively equal" natural men against whom we have a right to protect ourselves. The fetus is unequal and above all else dependent. That dependency and inequality is the essence of fetus-hood, so to speak. Self-defense doctrine with its Hobbesian background and overlay simply doesn't apply to such dependent and unequal "aggressors," indeed, the notion of aggression itself does not apply to such creatures.

Rape reform efforts to criminalize simple rape are also irrational, as Susan Estrich has discovered, and for the same reason: 
subjectively, "simple rapes" are harms, but from the point of view of masculine subjectivity, non-violent acts that don't threaten annihilation or frustration of projects can't possibly be "harmful." In both cases, we have tried to explain feminist reform efforts through the use of analogies that don't work and arguments that are strained. The result in both cases is internally inconsistent, poorly reasoned, weak, and ultimately vulnerable legal doctrine.

"Reconstructive feminist jurisprudence," I believe, should try to explain or reconstruct the reforms necessary to the safety and improvement of women's lives in direct language that is true to our own experience and our own subjective lives. The dangers of mandatory pregnancy, for example, are invasion of the body by the fetus and the intrusion into the mother's existence following childbirth. The right to abort is the right to defend against a particular bodily and existential invasion. The harm the unwanted fetus does is not the harm of annihilation, nor anything like it: it is not an assault, or a battery, or a breached contract, or an act of negligence. A fetus is not an equal in the state of nature, and the harm a fetus can do is not in any way analogous to that harm. It is, however, a harm. The fetus is an "other," and it is perfectly sensible to seek a liberal sounding "right" of protection against the harm the fetus does.

We need, though, to be more accurate in our description of the harm. Unwanted intercourse is "harmful" because it is invasive, not because it is (necessarily) violent. For that reason alone, the harm of intercourse is descriptively incommensurate with liberal concepts of harm. But it is not incommensurate with women's lives. The goal of reconstructive feminist jurisprudence should be to provide descriptions of the "human being" underlying feminist legal reforms that will be true to the conditions of women's lives. Our jurisprudential constructs-liberalism and critical theory-might then change as well to account for true descriptions of women's subjectivity.

\section{CONCLUSION: TOWARD A JURISPRUdence UNMODIFIED}

The "separation thesis," I have argued, is drastically untrue of women. What's worth noting by way of conclusion is that it is not entirely true of men either. First, it is not true materially. Men are connected to another human life prior to the cutting of the umbilical cord. Furthermore, men are somewhat connected to women during intercourse, and men have openings that can be sexually penetrated. Nor is the separation thesis necessarily true of men existentially. As Suzanna Sherry has shown, the existence of the en- 
tire classical republican tradition belies the claim that masculine biology mandates liberal values. ${ }^{75}$ More generally, as Dinnerstein, Chodorow, French, and Gilligan all insist, material biology does not mandate existential value: men can connect to other human life. Men can nurture life. Men can mother. Obviously, men can care, and love, and support, and affirm life. Just as obviously, however, most men don't. One reason that they don't, of course, is male privilege. Another reason, though, may be the blinders of our masculinist utopian visionary. Surely one of the most important insights of feminism has been that biology is indeed destiny when we are unaware of the extent to which biology is narrowing our fate, but that biology is destiny only to the extent of our ignorance. As we become increasingly aware, we become increasingly free. As we become increasingly free, we, rather than biology, become the authors of our fate. Surely this is true both of men and women.

On the flip side, the "connection thesis" is also not entirely true of women, either materially or existentially. Not all women become pregnant, and not all women are sexually penetrated. Women can go through life unconnected to other human life. Women can also go through life fundamentally unconcerned with other human life. Obviously, as the liberal feminist movement firmly established, many women can and do individuate, speak the truth, develop integrity, pursue personal projects, embody freedom, and attain an atomistic liberal individuality. Just as obviously, most women don't. Most women are indeed forced into motherhood and heterosexuality. One reason for this is utopian blinders: women's lack of awareness of existential choice in the face of what are felt to be biological imperatives. But that is surely not the main reason. The primary reason for the stunted nature of women's lives is male power.

Perhaps the greatest obstacle to the creation of a feminist jurisprudence is that feminist jurisprudence must simultaneously confront both political and conceptual barriers to women's freedom. The political barrier is surely the most pressing. Feminists must first and foremost counter a profound power imbalance, and the way to do that is through law and politics. But jurisprudence-like law-is persistently utopian and conceptual as well as apologist and political: jurisprudence represents a constant and at least at times a sincere attempt to articulate a guiding utopian vi-

75 Sherry, 72 Va.L.Rev. at 584 (cited in note 14). 
sion of human association. Feminist jurisprudence must respond to these utopian images, correct them, improve upon them, and participate in them as utopian images, not just as apologies for patriarchy. Feminism must envision a post-patriarchal world, for without such a vision we have little direction. We must use that vision to construct our present goals, and we should, I believe, interpret our present victories against the backdrop of that vision. That vision is not necessarily androgynous; surely in a utopian world the presence of differences between people will be cause only for celebration. In a utopian world, all forms of life will be recognized, respected and honored. A perfect legal system will protect against harms sustained by all forms of life, and will recognize life affirming values generated by all forms of being. Feminist jurisprudence must aim to bring this about and, to do so, it must aim to transform the images as well as the power. Masculine jurisprudence must become humanist jurisprudence, and humanist jurisprudence must become a jurisprudence unmodified. 